\title{
تقييم منهج الرياضيات في مراحل التعليم الأساسي في دولة الكويت من وجهة نظر معلمي مادة الرياضيات
}

$$
\text { إعـــــــاد }
$$

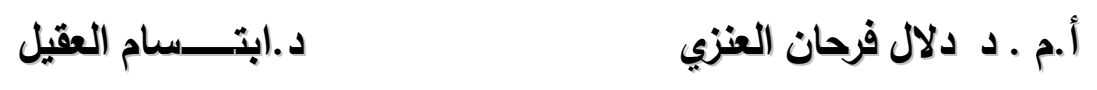

كلية التربية الأساسية - جامعة جلاسكو - بالمملكة المتحدة

مجلة الدراسات التريوية والانساتية ـ كلية التربية ـ جامعة دمنهور .

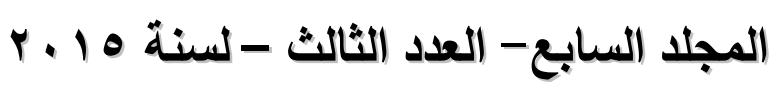


تقييم منهج الرياضيات في مراحل التعليم الأساسي في دولة الكويت د. دلال فرحان العنزي د. ابتسام العقل 
تقييم منهج الرياضيات في مراحل التعليم الأساسي في دولة الكويت من وجهة نظر معلمي مادة الرياضيات

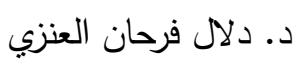

د. ابتسام العقيل

\section{ملخص الارلةة:}

هدفت الدراسة إلى تقييم محتوى منهج الرياضيات في مراحل التعليم الأساسية في دولة الكوبـت ( الابتدائية/ المتوسطة)، ومدى ترابط المضدون وتتوع طرق التدريس وتصميمها وتسلسل المعايير • تم تطبيق هذه الدراسـة في العام الدراسي

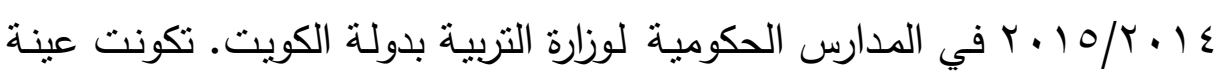

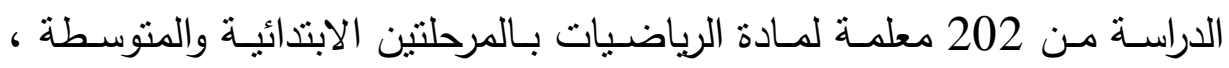

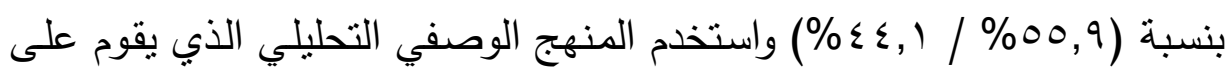
التسلسل المنطقي للأفكار، وذلك للوقوف على أهم جوانب القوة وجوانب الضـف في منهج الرياضيات. أثـارت الدراسـة إلـى نتـائج تقيـيم المعلمـات لمنـاهج الرياضـيات بالمرحلـة الابتدائيـة والمتوسطة بشكل عـام كانـت متوسطة المستوى، حيـث بلـغ المتوسط

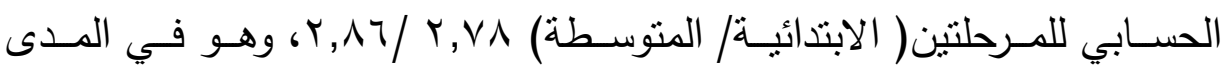
المتوسط للتقيهم. وترى معلمـات الرياضـيات أن تصـميم الدروس في المرحلـة الابتذائيـة يحتوى على خبرات كافيـة وفرص للمناقثـة تمكن الطالب من تطوير الفهم ولكنها لا ترتبط من حيث المحتوى بالحياة اليوميـة للطالب. بينمـا يفتقر محتوى منـاهج الرياضـيات في المرحلـة المتوسطة لأسـاليب الاستقصساء العلمي لري بصسورة متوازنـة ومتتوعـة ولا توفر أي فرصسة للمناقثـة تمكن الطلبـة من تطوير فهمهم. وكما ترى معلمات الرباضيات المناهج بنفس المستوى بجميع الصفوف الدراسـية بـالمرحلتين الابتدائيـة والمتوســة ولا يوجـد اخـتلاف مســتوى مـنـهج الرياضـيات مـن حيـث المحتـوى و تصـميم الـدرس، وتتظـيم المـواد، والتقبـيم ، والمسـاواة، وتسلسل المعايير باختلاف الصفوف الدراسية. في ضوء هذه النتائج 
تقييم منهج الرياضيات في مراحل التعليم الأساسي في دولة الكويت د. دلال فرحان العنزي د. ابتسام العقل

توصسي الدراسـة بضـرورة إعـادة النظر من قبل واضـعي منـاهج الرياضيات في المراحل الأساسية (الابتدائية/ المتوسطة) في دولة الكويت، وذللك بالنسبة لأبعاد

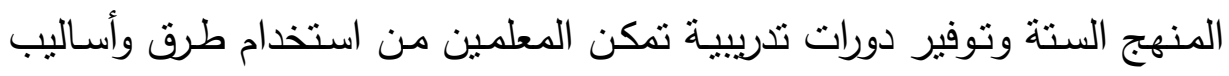

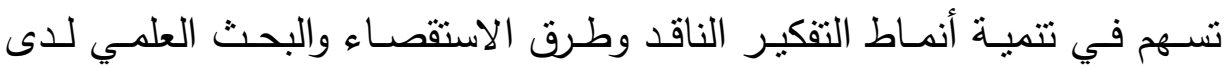
التلاميذ. 


\section{المقدمة:}

تعتبر مادة الرياضيات من الدعائم الأساسية لأي تقدم علمي، وهي من أكثر

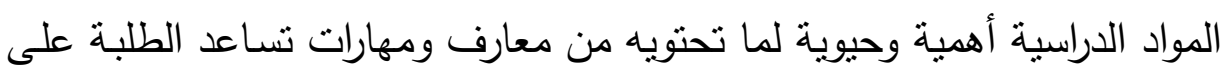

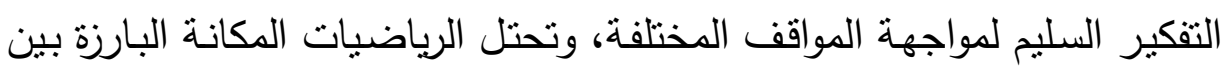

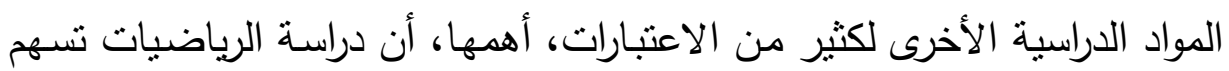

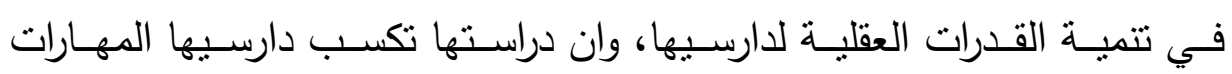

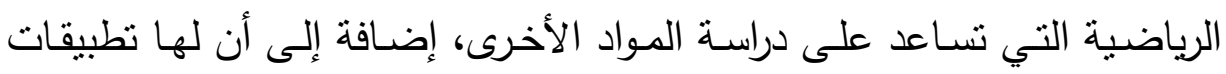

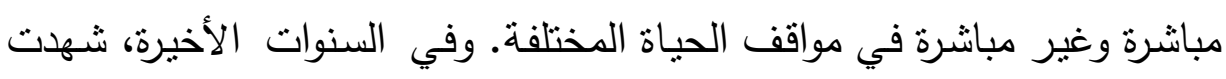
مناهج الرياضيات نطورات عديدة وبرزت نوجهات حديثة حول مناهج الرياضيات موني

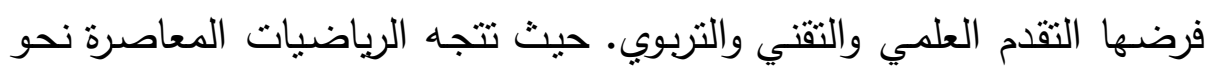
التجديد والتعميم والتركيز على المفاهيم والمدركات الأساسية بحيث يدرك التلميذ

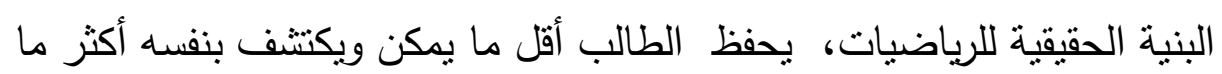

للمنهج المدرسي دورا جوهريا في عمليات التعلم والتعليم داخل المدرسة، إذ أنه

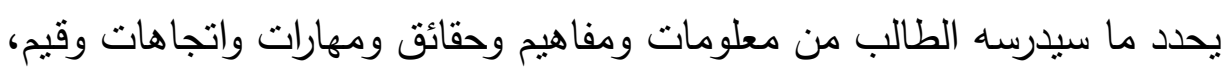

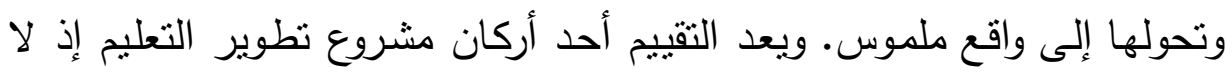
يمكن إحداث تطوير في أهداف ومحتوى المنهج التعليمي إلا بالاعتماد على ولى فئل

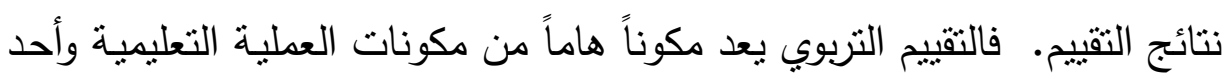
المرتكزات الأساسية التي ينهض عليها التعليم العام في مراحله المختلفة للحكم على النتائج التربوية التي يحققها التلاميذ خلال تعاملهم مـع المناهج الدراسية.

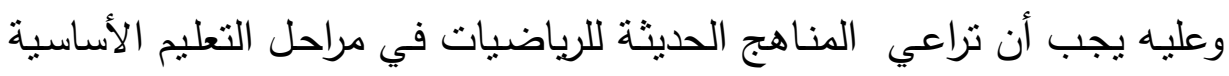

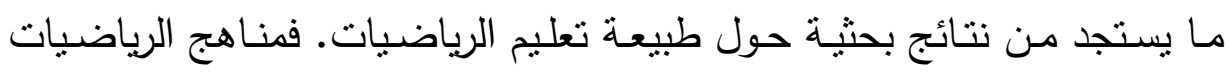

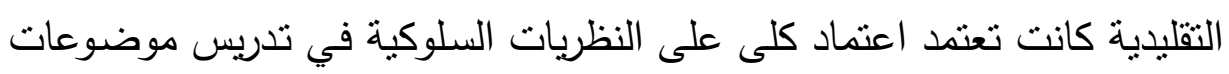

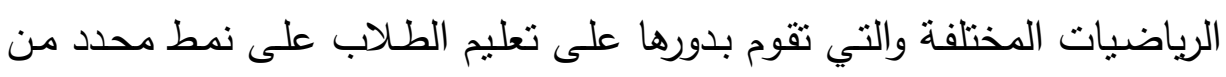


الاسئلة ( مثيرات معينـة) والتي تركز على طريقة الحفظ والاسترجاع لخطوات الحل والحقائق والمهارات الرياضية دون الربط بين الأفكار الرياضية وتطبيقاتها.

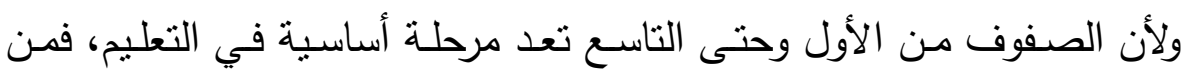

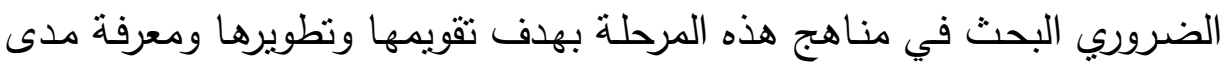

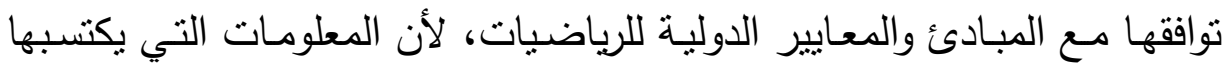
الطالب في هذه المرحلة تبقى ثابتة في ذاكرته، وتبقى بمثابة الأساس الذي ييني عليه نموه المعرفي لاحقًا.

\section{مشكلة البحث}

اظهرت نتائج الطلبة الكوينتين في الاختبارات العالمية TIMSS تدني مستوى تحصيل الطلبة في الرياضيات مقارنة بأداء طلبة البلدان المشاركة في الاختبار

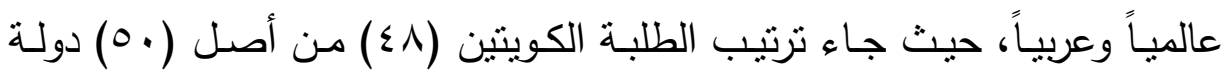

\begin{tabular}{|c|c|c|c|}
\hline & &.$($ TIMSS, 2011$)$ & شاركت في الاختبار \\
\hline \multirow[t]{2}{*}{$r+11$} & $r \ldots v$ & $r \ldots r$ & الرياضــيات/ الصــف \\
\hline & & & 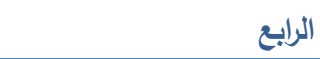 \\
\hline $0 .$. & $0 .$. & $\leqslant 90$ & المتوسط الدولى \\
\hline ( $\varepsilon r) \leqslant r \leqslant$ & ---- & --- & الإمارات \\
\hline (ะ1) $\leqslant r \uparrow$ & ---- & --- & البحرين \\
\hline (Ev) roq & $(T r)$ TrV & $\left(r_{0}\right) r q 9$ & ت ت تونس \\
\hline--- & $(r q) r V \Lambda$ & --- & الجزائر \\
\hline$(\leqslant 0) \leqslant 1$. & --- & --- & السعودية \\
\hline$(\Sigma \tau)$ r so & ---- & --- & عمان \\
\hline$(\varepsilon \varepsilon) \leqslant 1 T$ & Tro & --- & قطر \\
\hline$(\varepsilon \wedge) r \leqslant r$ & $(\Gamma \xi) \Gamma 17$ & --- & الكويت \\
\hline (0.) Y^E & $(r) r \leqslant 1$ & $(r \varepsilon) r \leqslant V$ & المغرب \\
\hline
\end{tabular}

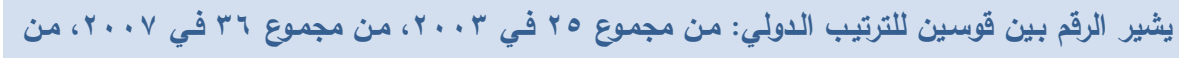

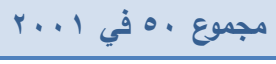

جدول ا تطور أداء طلبـة الصف الرابـع في الرياضيات في نتائج اختبار TIMSS 
في ضوء هذه النتائج أكدت دراسـة TIMSS على ضـرورة مراجعة المنـاهج

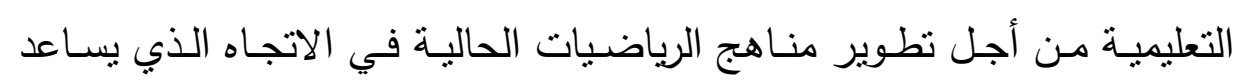

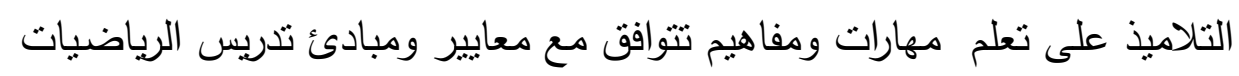

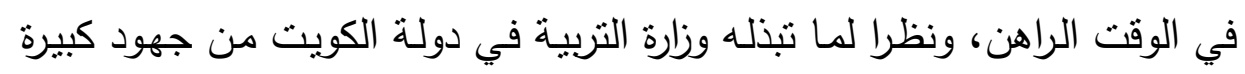
في عملية تطوير المناهج وتدريب المعلمين والمعلمات على استراتيجيات التدريس

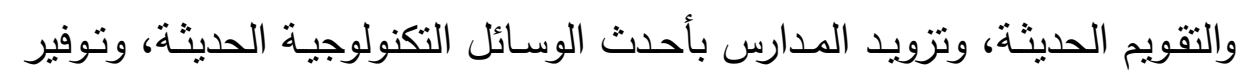

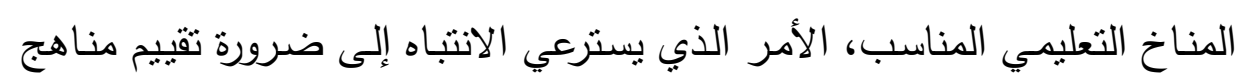

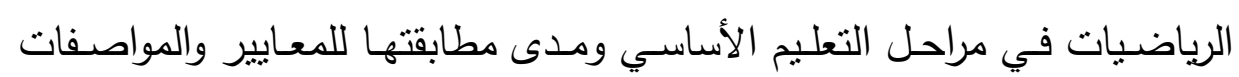
العالمية.

لقد أصدر المجلس القومي لمعلمي الرياضيات في الولايات المتحدة الأمريكية

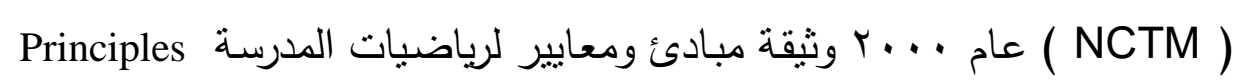
and Standards for School Mathematics ( NCTM, 2000).

$$
\text { مبادئ تعليم الرياضيات: }
$$

ا.مبدأ المساواة: لقد اعتبر المجلس المساواة شرطا أساسيا للتميز في تدريس

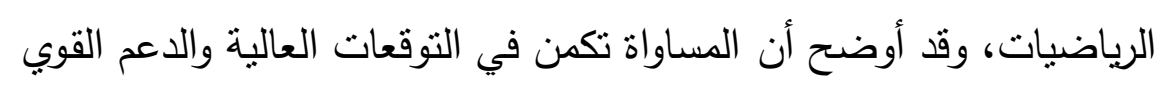

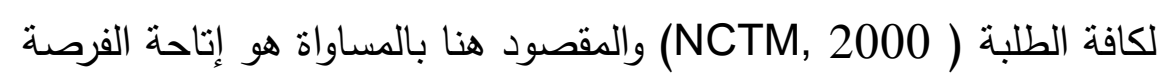
لكل طالب لإظهار أقصى قدراته الرياضية وتحقيق الحد الأعلى من الفهح حسب امكانياته واجتهاده، ولا يقصد بالطبع أن يتم تعليم الجميع نفس الكمية من الرياضيات وبنفس الطريقة المتعقةة.

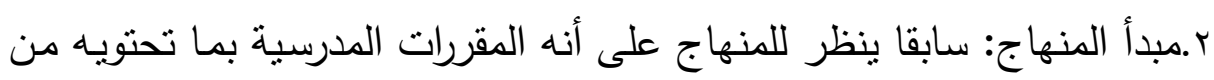

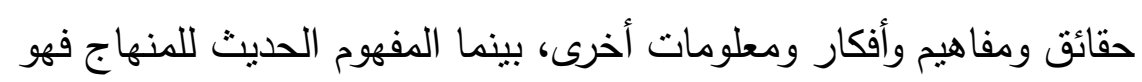
أكثر شمولاً، حيث أصبح ينظر إلى المنهاج على أنه يشمل كافة الخبرات

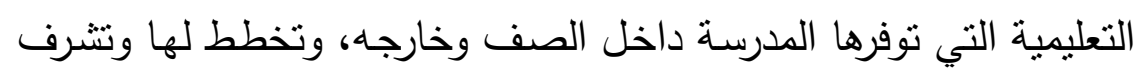

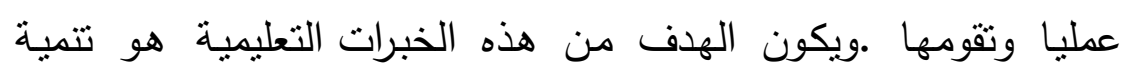


تقييم منهج الرياضيات في مراحل التعليم الأساسي في دولة الكويت د. دلال فرحان العنزي د. ابتسام العقل

معلومات التلميذ ومهاراته واتجاهاته بما يحقق الأهداف العامة للتعليم والأهداف الخاصة للمادة الدراسية.

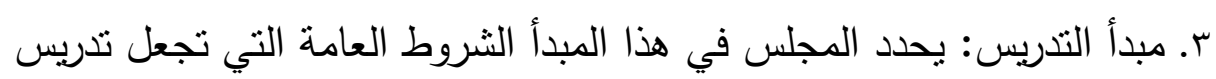
الرياضيات فعالا. فيقرر أنه على المعلم أن يفهم الرياضيات بعدق ويند ويفهر

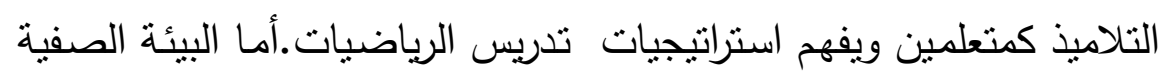
التي يحدث فيها التدريس والتعلم ,فيشترط المجلس أن تكون متحدية للطلبة

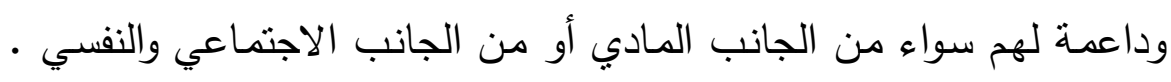

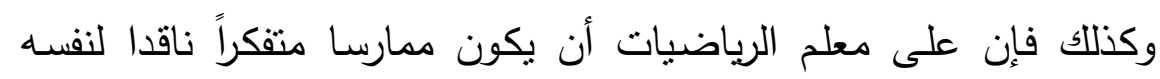
باستمرار باحثا عن كل ماهو جديد في مجال الرياضيات وتربوياتها.

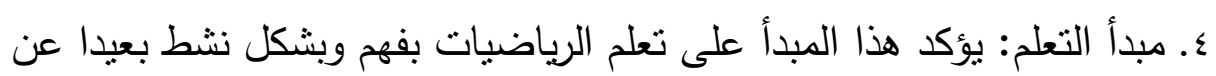
السلبية والتلقي الأعمى •وبهذا ,فإن المجلس ينادي بمركزية دور الطالب في لئي

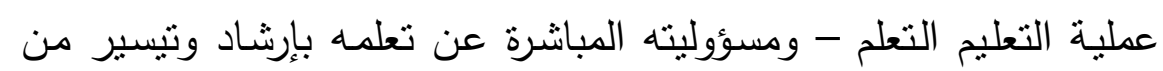
المعلم.

ه. مبدأ التقويم: يؤكد هذا المبدأ على أن التقويم يجب أن يدعم تعلم رياضيات

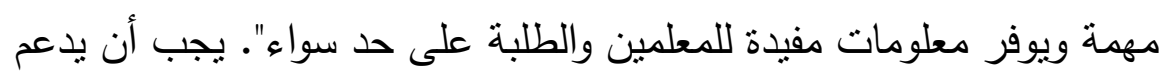

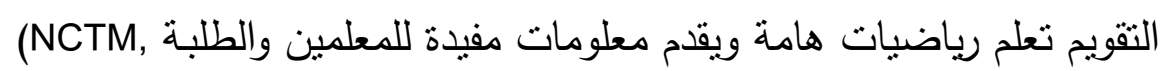
.2000) ז. مبدأ التقنية: أكد المجلس من خلال هذا المبدأ على ضرورة الاستفادة من النقنيات المنوفرة في تعليم الرياضيات وتعلمها ـوينطلق المجلس في هذا من فن فئن أن التقنيات تعزز التعلم وتتيح الفرصة للطلبة للتركيز على الأفكار والمفاهيم

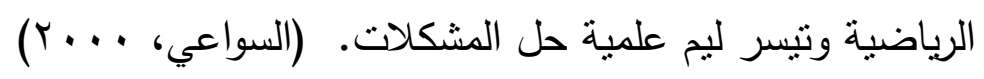




\section{أهداف البحث}

تهدف هذه الدراسة للكثف عن:

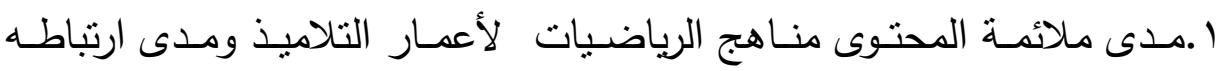

بحياتهم اليومية

r.مدى توافر خبرات كافيـة وفرص للمناقثـة تمكن الطالبـات مـن تطوير الفهم

العميق للمحتوى

r.مدى مطابقة المنهاج لمبادئ تعليم الرياضيات وتحقيق المعايير العلمية من

خلال التفكير ونطبيق المهارات ويساعد في تطبيق المعايير المحلية.

ـ .التعرف على المقترحات التي تراها معلمات مادة الرياضيات في مراحل التعليم

الأساسية لزيادة فاعلية تعليم منهج الرياضيات في المرحلة في دولة الكويت.

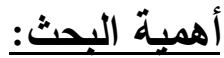

تكتسب هذه الدراسة أهميتها نظراً للاعتبارات التالية:

ا.قلة الدراسات التي تعالج جانب التقييم في منهج الرياضيات في المرحلة

الابتدائية والمتوسطة في دولة الكويت.

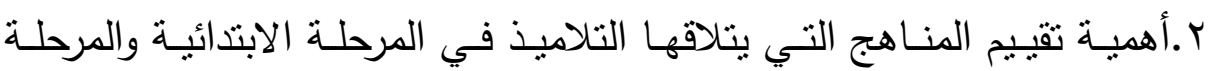

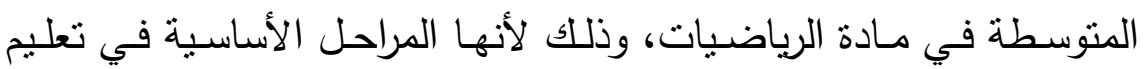

الرياضيات.

r.يمكن أن يساهم البحث في اتخاذ خطوات عملية لتحسين منهج الرياضيات في

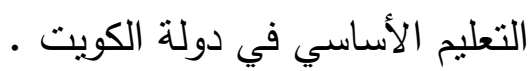

ع .قد تزود هذه الدراسـة القائمين على تخطيط المناهج وتطويرها بقائمسة معايير

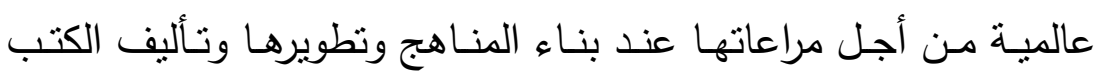

المدرسية. 


\section{مصطلحات البحث:}

الآثبn:

"العملية المنهجية التي تتضمن جمع معلومات عن سمة معينة (بالقياس الكمي أو غيره) ثم استخدام هذه المعلومات في إصدار حكم على هذه السمة في ضوء أهداف محددة سلفاً لمعرفة مدى كفايتها" (سمارة، وأخرون، 919 (1). وهو يكثف للقائمين على التعليم عن جوانب القوة والضعف في النظام التعليمي ومدى قدرة هذا النظام على إعداد الفرد بشكل بمكنه من القيام بدور فاعل في تلبية حاجات المجتمع مـع مراعاة ظروف التغيرات التي يمر بها المجتمع من تطورات عالميـة

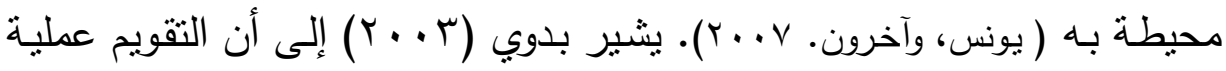
شـاملة لكل عناصـر الموقف التعليمي من معلم ومتعلم ومـادة دراسية (موضسوع

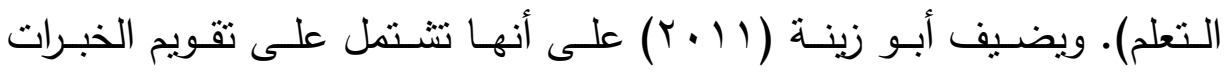
التعليميـة التي تكون فحوى المنهاج من حيث تحقيقها للأهداف وانسـامها مـع بعضها وحداثتها وحسن تتظيمها وتوزيعها.

بذكر الخوالده، وأخرون (11 ( ب) أن للتقويم ثناث وضائف رئيسية وهي: تشخصية: التعرف على واقع منظومة المنهاج من حيث الأسس وتوازن الأهمية النسـبية لكـل منهـا والاتسـاق بـين النتاجـات في مجالاتهـا ومسـتوباتها، واعتمادهـا على المبـادئ ذات العلاقـة بالبنـاء وطبيعـة العلاقات فيمـا بين مكوناتها، والعلاقات مع المنظومات الأخرى ذات العلاقة. علاجيـة: أتخـاذ القرارات، والمباشـرة بـاجراءات إصـلاحية للمـهـج أو تطويريـة أو تعزيزيـة، فـي صـورة إعـادة طباعـة الكتـب الدراسـية المقـررة واسـتبعاد الموضوعات أو الأفكار الثـاذة وادخال المعلومات والحقائق التي لا تقبل التأوبل. الوقائبة: الحصول على تغديـة راجعة عن خلل مـا في مكون من المكونات أو أكثر بسبب تعديل مكون آخر • 
وعليـه فـأن المفهـوم الإجرائسي للتقيـيم في هذه الدراسـة يركز على الوظيفة

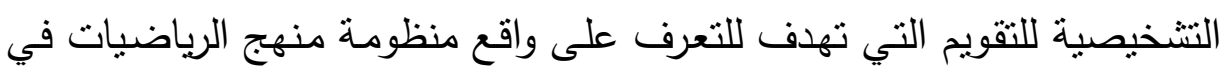

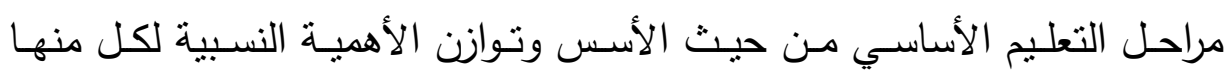

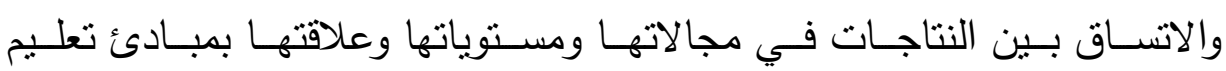
الرياضيات ومعاييرها. المنهج (المباصناس

المنهـج بـالمفهوم الحديث يثـتمل على " جميـع الخبـرات التعليميـة المنهجيـة (الصفية واللاصفيه) التي يتعرض لها الطالب، والتي تنولى المدرسة التخطيط لها

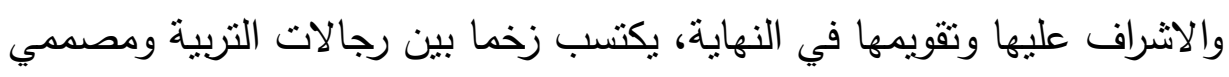

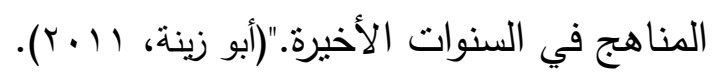

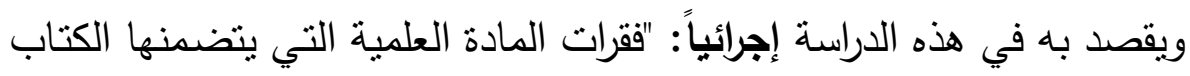
المدرسي ويقوم معلم الرياضيات في المرحلة الابتدائية والمتوسطة بتدريسه

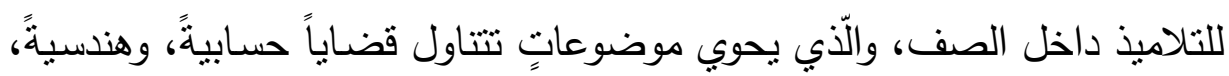
منتوعة.

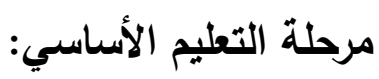

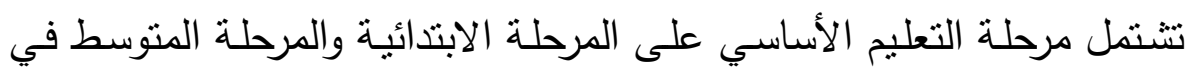
سلم التعليم في دولة الكويت. المرحلة الابتدائية : ذكر عبد الرحمن ( 1991) " أن المرحلة الابتدائية هي القاعدة التي يرتكز عليها إعداد الناشئين للمراحل التالية من حياتهم وهي مرحلة

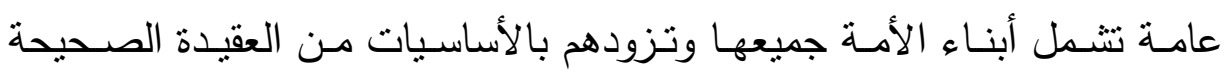

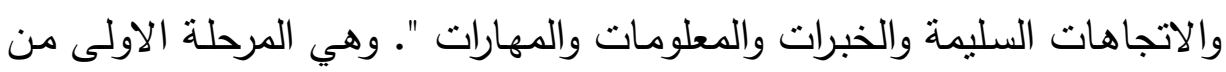
مراحل التعليم العام في دولة الكويت وهي عبارة عن خمس سنوات في سلم التعليم العام ويتراوح سن التلاميذ فيها ما بين السادسة واحادية عشرة. 
المرحلة المتوسطة: تقع المرحلة المتوسطة ما بين المرحلة الابتدائية التي تمثل بداية سلم التعليم العام والمرحلة الثانوية التي تمثل نهايته، ويلتحق بها التلميذ بعد لهد

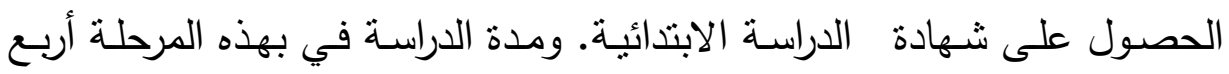

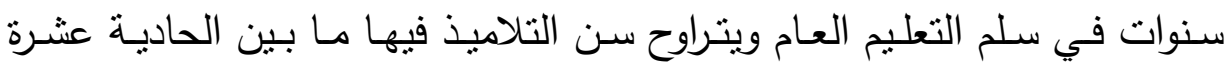
والخامس عشر ، يعقد في نهايتها امتحان عام بنظام الفصلين الدراسيين، يحصل

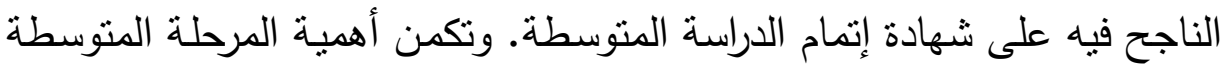

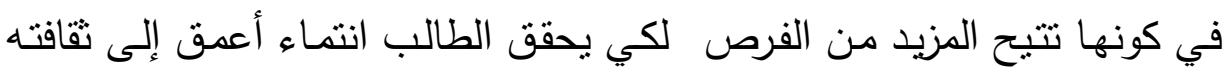
الأصلية، فضلا عن أنها تتيح المزيد من الفرص لتتمية قدرات واستعدادات الطلبة بما يعدهم للاختيار التعليمي بين التخصص الأدبي أو العلمي.

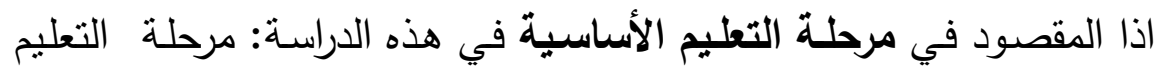
الرسمي الذي يتتاول التلميذ من سن السادسة، إلى الخامس عشرة، فيتعهده

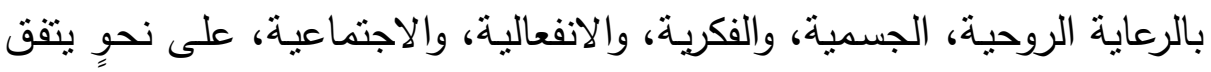
مـع طبيعته كطفلٍ، ومـع أهداف المجتمع الّّني يعيش فيه، وهي مرحلتي التعليم الابتدائي والمتوسط. الاراسات السابقة:

في دراسة عن مستوى وجودة محتوى منهاج الرياضيات الفلسطيني للصفوف الثالث والثرابع والخامس الاساسي في ضوك معايير NCTM (درويش، واخرون

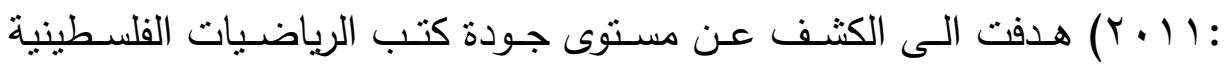

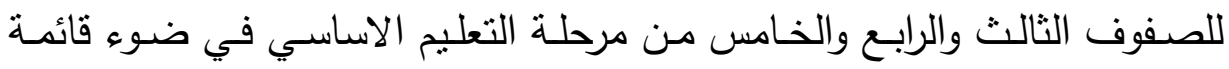
معايير NCTM وقد تم توظيف استبيان تعتمد بنوده على معايير NCTM تم

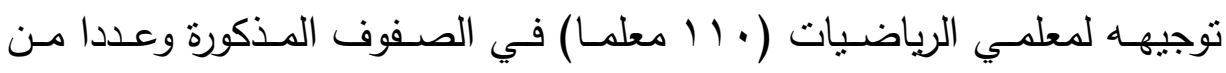

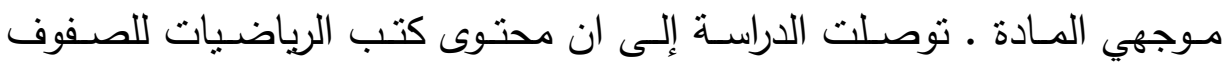
المذكورة يفتقر وبصورة واضحة لتوافر عدد من معايير الجودة في ضوء معايير

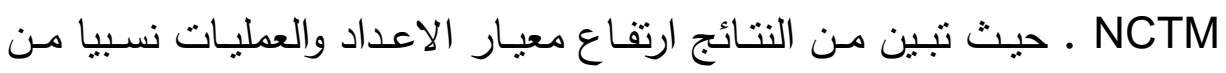


الجودة ، اذ ان الوزن النسبي لدرجة توافره في مناهج الرياضيات للصفوف الدذكرة

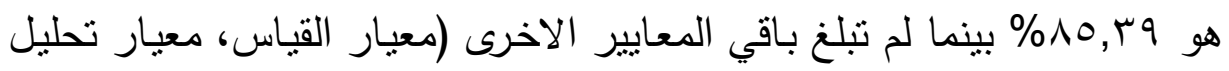

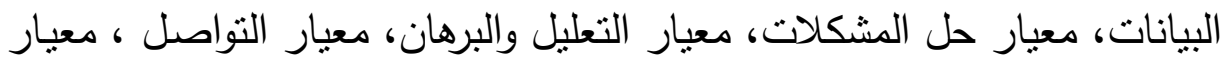

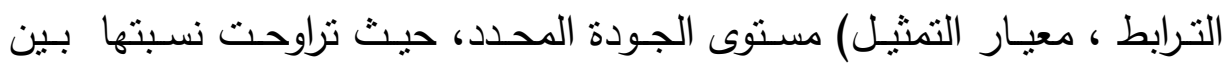

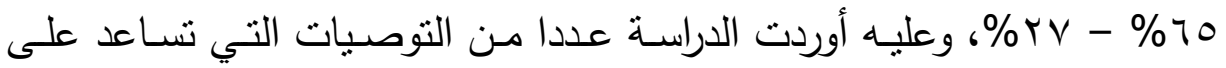

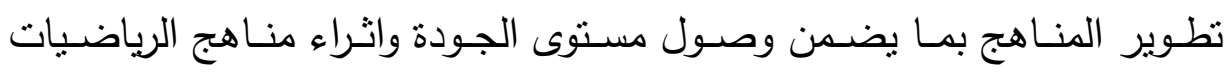

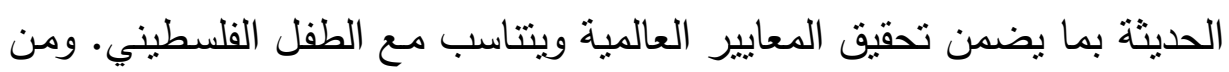
أهم هذه التوصيات هي تتظيم ورش عمل لمعلمي ومثرفي مادة الرياضيات

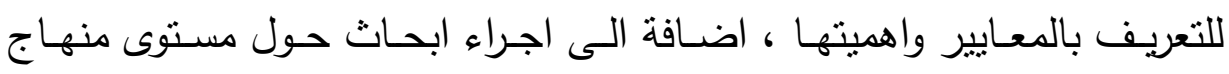

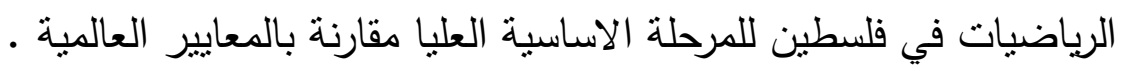
وفي دراسة أخرى عن تقويم كتاب الرياضيات للصف الثامن الأساسي الجديد

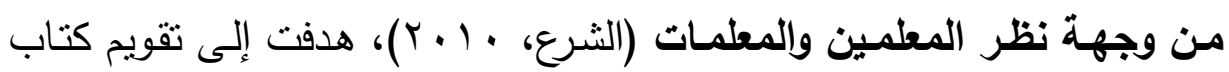

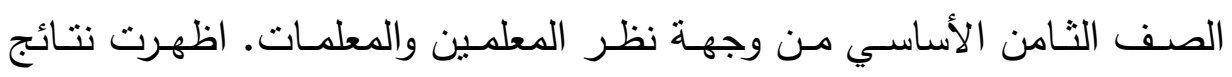
الدراسة أن التقدير التقويمي العام للكتاب بدرجة منوسطة، وكذللك فقد جاء التقدير

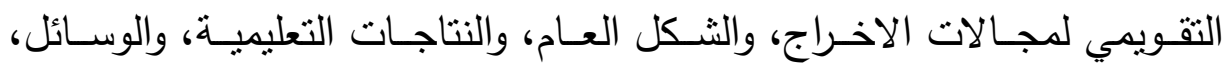

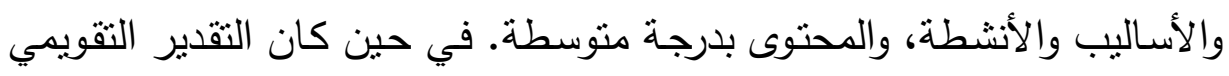

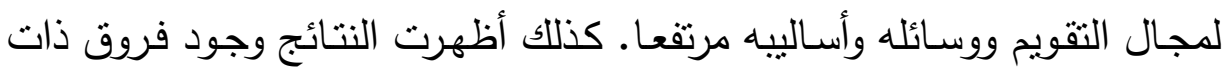

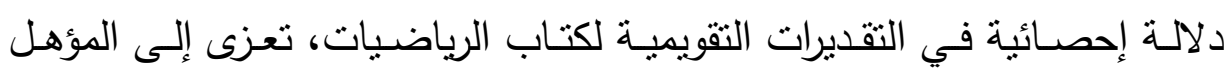

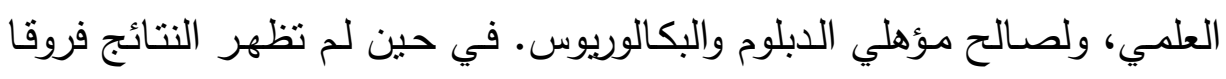

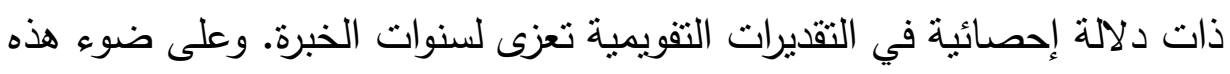

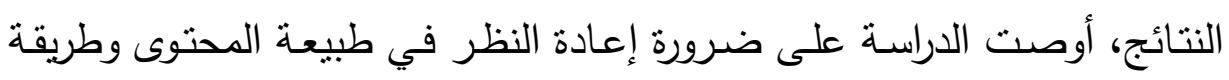

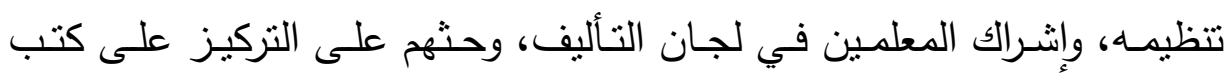
الرياضيات الجديدة في بحوثهم للاراسات العليا. 
وفي دراسـة تقويميـة لمنـاهج الرياضـيات المطورة وفق الاقتصـاد المعرفي

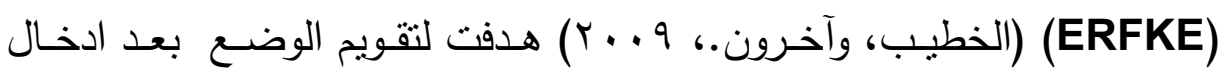

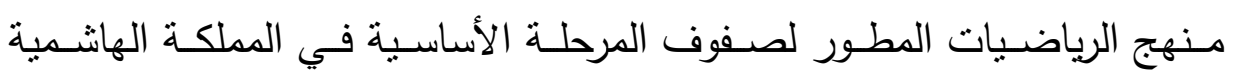

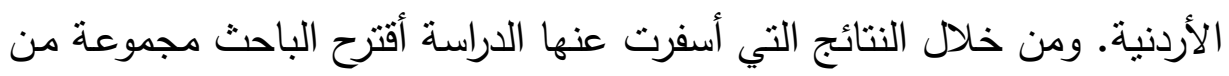

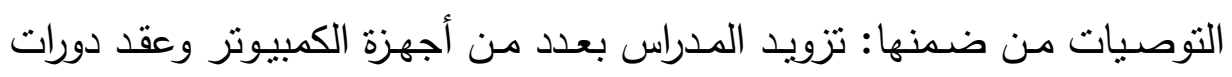

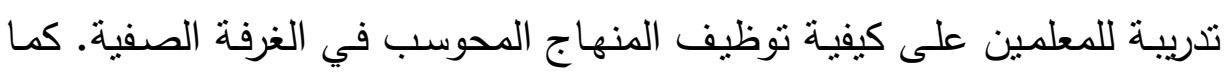

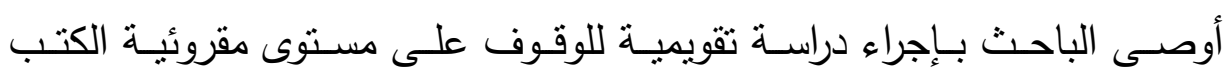

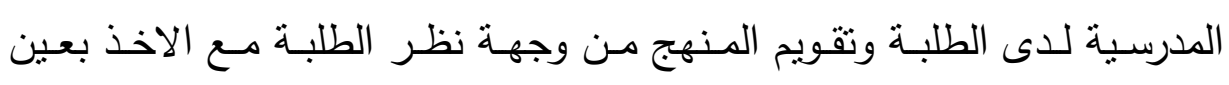
الاعتبار مستوى تحصبلهم العلمي.

في دراسة "واقع سياسات التقويم وممارساتها الصفية في المدارس الابتدائية

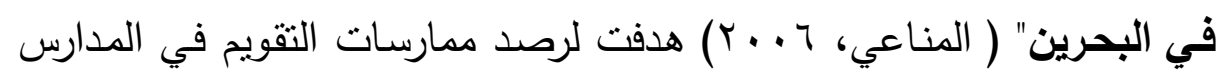

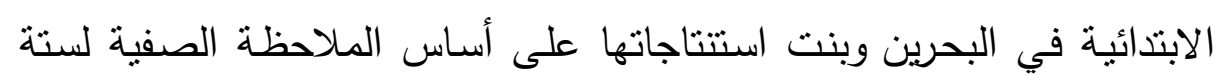

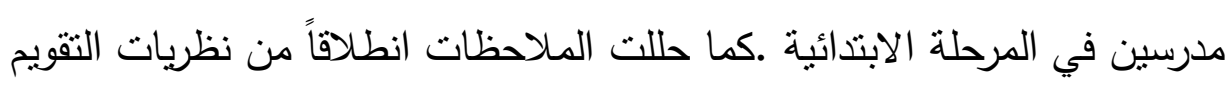
التربوي الحديثة واستتاداً إلى الإطارات والسياق الذي تمارس فئه فيه العملية التعليمية

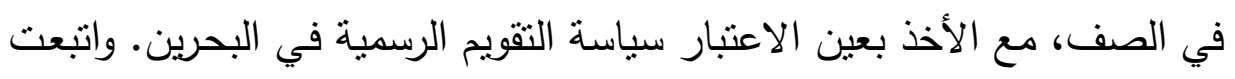

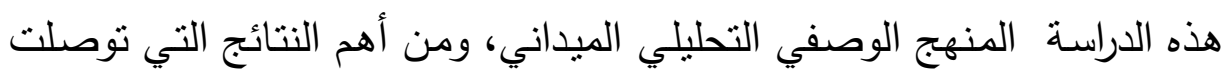

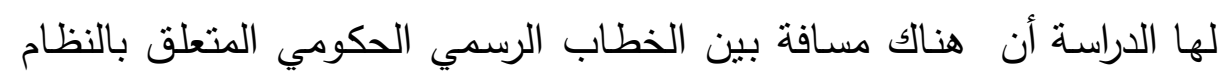

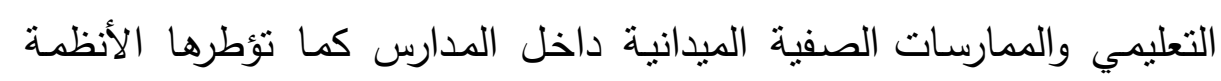
المرعية التتفيذ. كما وضعت الدراسة تصور لإمكانات التحسين والعلاج والتطوير للمستقبل استتاداً على مواقع الخلل المشار إليها. أسئلة البحث:

هدفت الدراسة إلى تقييم محتوى منهج الرياضيات في مراحل التعليم الأساسية ومدى ترابط المضمون وتتوع طرق التذريس وتصميمها وتسلسل المعايير . وقد حاولت الدراسة الإجابة عن الأسئلة التالية : 
ا .ما مستوى تقييم مناهج الرياضيات بصفوف المرحلة الابتدائية من وجهة نظر

$$
\text { المعلمات؟ هن }
$$

r.هل توجد فروق ذات دلالـة احصـائية في تقييم منـاهج الرياضيات بالمرحلـة

$$
\text { الابتدائية تعود للصف الدراسي؟ دات دله }
$$

r.ما مستوى تقييم مناهج الرياضيات بصفوف المرحلة المتوسطة من وجهة نظر

$$
\text { المعلمات؟ هن }
$$

ع ـهل توجد فروق ذات دلالـة احصـائية في تقييم منـاهج الرياضيات بالمرحلـة

$$
\text { المتوسطة تعود للصف الدراسي؟ }
$$

ه.ما مستوى تقييم مناهج الرياضيات عامة بالمرحلتين الابتدائية و المتوسطة من لمن

$$
\text { وجهة نظر المعلمات؟ }
$$

7 ا.هل توجد فروق ذات دلالـة احصـائية في تقيم منـاهج الرياضيات بكل مـن المرحلة الابتدائية والمرحلة المتوسطة؟ دوفي دوانه

\section{المنهج المتبع:}

يستخدم الباحثون المنهج الوصفي التحليلي الذي يقوم على التسلسل المنطقي

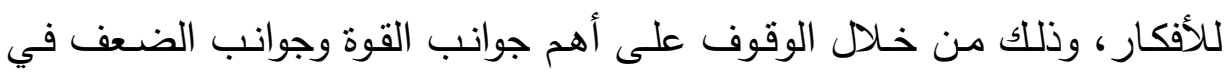
منهج الرياضيات في المرحلتين الابتدائية والمتوسطة. حدود البحث:

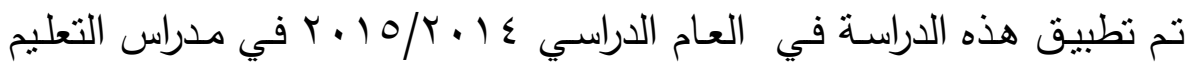
الحكومية لوزارة التربية بدولة الكويت (الابتدائية /المتوسطة).

\section{عينة الاراسة}

تكونت عينة الدراسة من 202 معلمة لمادة الرياضيات بالمرحلتين الابتدائية والمتوسطة، بنسبة 90,9\% بالمرحلة الابتدائية، و 1, ؟ـ\% بالمرحلة المتوسطة.

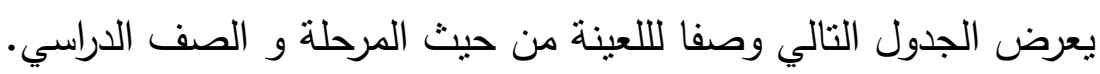


تقييم منهج الرياضيات في مراحل التعليم الأساسي في دولة الكويت د. دلال فرحان العنزي د. ابتسام العقل

جدول2 : توزيع العينة حسب الصف الدراسي

\begin{tabular}{|c|c|c|c|}
\hline \multicolumn{2}{|c|}{ المرطلة المتوسطة } & \multicolumn{2}{|c|}{ المرطلة الابتدائية } \\
\hline العلد & الصف & العلدد & الصف \\
\hline 25 & 6 & 25 & 1 \\
\hline 22 & 7 & 21 & 2 \\
\hline 21 & 8 & 16 & 3 \\
\hline 21 & 9 & 25 & 4 \\
\hline & & 26 & 5 \\
\hline 89 & المجموع & 113 & المجموع \\
\hline $44.1 \%$ & $\%$ & $55.9 \%$ & $\%$ \\
\hline
\end{tabular}

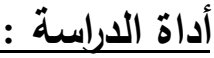

حساب صدق و ثبات الاستبيان :تم إعادة حساب صدق و ثبات الاستبيان

المستخدم فى الدراسة الحالية، وذللك بالأساليب التالية:

ا .حسـاب صدق التكوين : تم حساب صدق التكوين الداخلي للاستبيان و

ذلك بحسـاب الاتسـاق الداخلي لعلاقـة كل فقرة بـالمحور الذى تمنلـهـ

باسـتخدام معامـل ارتبـاط بيرسـون و يعرض جدول (Y) لعلاقـة الفقرات

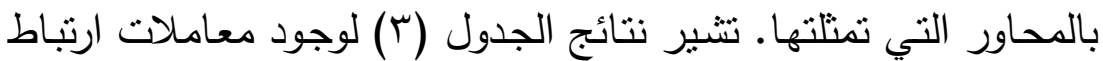
دالة إحصائيا بين جميع الفقرات و بين محاور الاسنييان، وهو ما يشير إلى توفر صدق التكوين الداخلي بالمحاور •

\begin{tabular}{|c|c|c|c|c|c|c|c|c|c|c|c|}
\hline \multicolumn{2}{|c|}{ تسلسل المعايير } & \multicolumn{3}{|c|}{ المساواة } & \multirow{2}{*}{ التقييم } & \multicolumn{3}{|c|}{ تنظيم المواد } & \multirow{2}{*}{ الدرسم } & \multicolumn{2}{|c|}{ المحتوى } \\
\hline معامـــل & |الفقرة & معامــــل & الفقرة & معامـــلـ & & معامـــل & الفقرة & معامـــل & & معامــــل & الفقرة \\
\hline $.921 \% *$ & $1 \varepsilon$ & $.913 \% *$ & ir & $.737 \% *$ & 1. & $.737 \% *$ & $\mathrm{v}$ & $.809 \% *$ & r & $.889 \% *$ & 1 \\
\hline $.910 * *$ & 10 & $.806 \% *$ & r & $.889 \%$ & 11 & $.889 \%$ & $\wedge$ & $.733^{* *}$ & $\varepsilon$ & $.816 \%$ & $r$ \\
\hline & & & & & & $.861 \% *$ & 9 & $.769^{* *}$ & 。 & & \\
\hline
\end{tabular}

"دالة عند مستوى 1 ., .

جدول ץ: معاملات الارتباط بين الفقرات ومحاورها 
مجلة الاراسات التريوية والانسانية ـ كلية التربية ـ جامعة دمنهور . المجلد السابع - العدد(ץ) - لسنة م 10

\begin{tabular}{|c|c|c|c|c|c|c|c|}
\hline تسلســـل & المساواة & التقييم & تتظيم المواد & تصـــميم & المحتوى & الاسلى الكتبيان & \\
\hline & & & & & & & الكلى \\
\hline & & & & & & $.641 * *$ & المحتوى \\
\hline & & & & & $.333 * *$ & .685 & تصميم اللدس \\
\hline & & & & $.461 * *$ & $.551^{* * *}$ & .900 & تنظيم العواد \\
\hline & & & $.668 * *$ & $.574^{* *}$ & $.359^{* * *}$ & .799 & التقيييم \\
\hline & & $.585 * *$ & $.740 * *$ & $.472 * *$ & $.429 * *$ & .836 & المساواة \\
\hline & $.616_{*}^{*}$ & $.572^{* *}$ & $.674^{* *}$ & $.455 * *$ & $.384^{* *}$ & .790 & المعايير تسلســــل \\
\hline
\end{tabular}

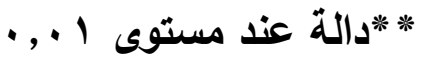

\section{جدول ع : مصفوفة معاملات الارتباط بين محاور الاستبيان}

ويظهر جدول (ع) حساب مصفوفة معاملات الارتباطات بين الدرجة الكلية

للمقياس و بين أبعاده الفرعية لحساب الصدق الداخلي للاستبيان، حيث تشير قيم معاملات الارتباط بالمصفوفة وجود معاملات ارتباط موجبة و دالة احصائيا بين جميع محاور الاستبيان مع بضعها البعض و بينها وبين الدرجة الكلية للاستبيان. وهو ما يشير الى توفر صدق التكوين بالاستبيان.

r أحسـاب الثبات :تم حسـاب ثبات الاستبيان باستخدام معامل الفا كروبـاخ

للثبات لكل من محاور الاستبيان ودرجته الكلية، كما فى الجدول التالى :

\begin{tabular}{|c|c|c|}
\hline معامل الفا كروياخ & عدد الفقرات & \\
\hline .911 & 10 & الاستبيان الكلى \\
\hline .620 & r & المحتوى \\
\hline .656 & $r$ & تصميم الدرس \\
\hline .846 & $r$ & تنظيم المواد \\
\hline .761 & $r$ & التقييم \\
\hline .631 & $r$ & المساواة \\
\hline
\end{tabular}


تقييم منهج الرياضيات في مراحل التعليم الأساسي في دولة الكويت د. دلال فرحان العنزي د. ابتسام العقل

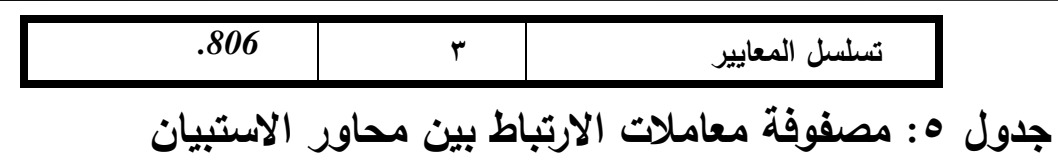

تشير نتائج الجدول (0) إلى أن معامل الثبات الكلى للاستبيان بلغ (1 (9, •)

وهى معامل ثبات مرتفع و دال على الثبات و الاستقرار بالاستبيان، وتراوحت

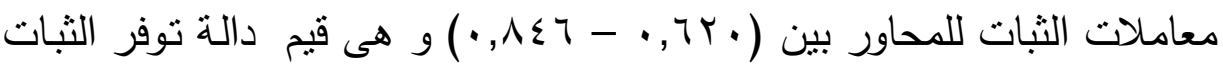

بمحاور الاستبيان.

نتائج الدراسةة:

للإجابة على أسئلة الدراسـة تم حساب كل التكرارات و النسب المئوبـة و من

المتوسط الحسابي و الانحراف المعياري ، لكل من فقرات الاستبيان و محاوره ،

وتم اعتماد المستويات التالية للتقييم:

من 1 - 1, 1, منخفض جدا

من

من ا Y, Y - ع, ז متوسط

من 1 \&,

من ا r, ع - - ه مرتفع جدا.

السـؤال الأول : مــا مسـتوى تقيـيم منـاهج الرياضـيات بصـفوف المرحلة

الابتدائية من وجهة نظر المعلمات؟

\begin{tabular}{|c|c|c|c|c|}
\hline الترتيب & المستوى & المعيارى & 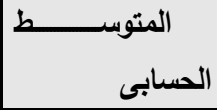 & \\
\hline 4 & متوسط & .973 & 2.77 & المحتوى \\
\hline 1 & متوسط & .813 & 2.86 & تصميم الدرس \\
\hline 2 & متوسط & 1.093 & 2.82 & تنظيم المواد \\
\hline 5 & متوسط & .985 & 2.74 & التقييم \\
\hline 6 & متوسط & 1.147 & 2.70 & المساواة \\
\hline 3 & متوسط & .982 & 2.79 & تسلسل المعايير \\
\hline & متوسط & .799 & 2.78 & المجموع \\
\hline
\end{tabular}


مجلة الاراسات التربوية والانسانية ـ كلية التربية ـ جامعة دمنهور . المجلد السابع- العدد(ץ) - لسنة 10 . ب

جدول \': المتوسطات والانحرافات المعيارية لارجة التقييم لمنهج الرياضيات

\section{في المرحلة الابتدائية}

تشير نتائج الجدول إلى إن تقييم المعلمات لمناهج الرياضيات بالمرحلة

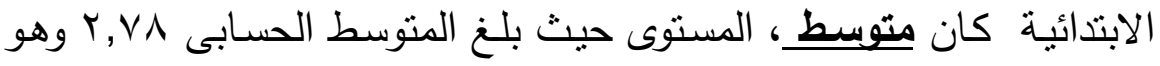
فى المدى المتوسط للتقبيم.

وجاء تقييم جميع محاور الاستبيان فى المدى المتوسط بمتوسطات بين

$$
r, V \cdot-r, \wedge T
$$

وجـاء فى الترنيب الأول محور تصميم الدرس، و فى الترتيب الأخير

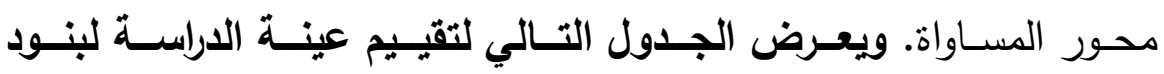

\begin{tabular}{|c|c|c|c|c|c|c|}
\hline الترتيب & | المستوى & 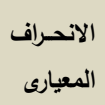 & الحسابى المتوســــــ & 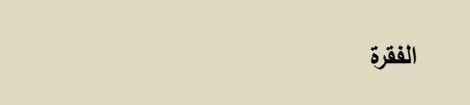 & e & 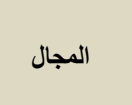 \\
\hline$r$ & متوسط & 1.223 & 2.93 & ما درجة ملائمة المحتوى لعمر الطلاب & 1 & \multirow[b]{2}{*}{ المحتوى } \\
\hline 10 & متوسط & .995 & 2.61 & اليويمة دا درجة أهمية المحتوى من حيث ارتباطه بالحياة & $r$ & \\
\hline$\wedge$ & متوسط & .970 & 2.78 & متوازنة ومنوعة يستخدم نمـاذج الاستقصــاء العلمس بصـورة & $r$ & \multirow{3}{*}{ تصميم الدرس } \\
\hline 0 & متوسط & 1.002 & 2.82 & هلى فهمهم للمحتوس الطـلاب الأنثطة بطريقـة فعالـة تـلـل & $\varepsilon$ & \\
\hline 1 & 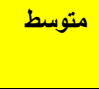 & 1.109 & 2.96 & الطلاب من تطوير الفهر خبات كافية و فرص للمناقثة تمكن & 0 & \\
\hline$r$ & متوسط متط & 1.288 & 2.95 & خلفية واضحة و كافية للمعلومات المواد التى يستخمها المعلم على & 1 & \multirow{4}{*}{ تنظيم المواد } \\
\hline 7 & متوسط & 1.255 & 2.80 & التعليم من خلال مراحل الدرس هـلك تعليمـات واضــة و محـدةة تـــمم & V & \\
\hline V & متوسط & 1.425 & 2.78 & 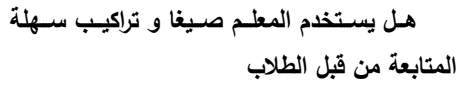 & $\wedge$ & \\
\hline 1. & متوسط مت & 1.429 & 2.76 & مسبقا مل تم تحديد الوسـائل اللازمـة لتنفيذ المنهج & 9 & \\
\hline ir & متوسط & 1.169 & 2.72 & المعلمون مزودون بالادوات اللازمة التقيم جميع مستويات الطلاب و & 1. & \multirow{2}{*}{ التقييم } \\
\hline 9 & متوسط & 1.052 & 2.77 & الرسمى هـل يراعسى التفيـيم البعديين الرسـى و غير & 11 & \\
\hline
\end{tabular}


تقييم منهج الرياضيات في مراحل التعليم الأساسي في دولة الكويت د. دلال فرحان العنزي د. ابتسام العقل

\begin{tabular}{|c|c|c|c|c|c|c|}
\hline $1 \leqslant$ & متوسط & 1.593 & 2.69 & قدراتـه الرياضية وتحقيق الفرصـة لكل طالب لإظهـار أقصى الأعلى من الفهم & Ir & \multirow[t]{2}{*}{ المساواة } \\
\hline IT & متوسط & 1.115 & 2.71 & المتنوعة لكل طالب الاستراتيجيات الحاجـات الخاصـة و & ir & \\
\hline 11 & متوسط & 1.078 & 2.73 & 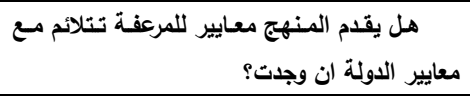 & $1 \leqslant$ & \multirow{2}{*}{ تسلســـــــل } \\
\hline$\varepsilon$ & متوسط & 1.074 & 2.84 & 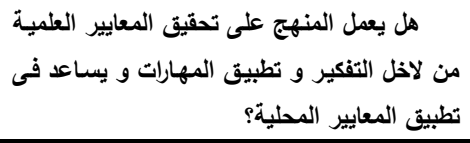 & 10 & \\
\hline
\end{tabular}

جدول V: نسب الاستجابة لبنود استبيان تقييم منهج الرياضيات بالمرحلة الابتدائية

تبـين نتـائج الجـدول (V) أن مسـتويات تقيـيم بنـود اسـتبيان تقيـيم منــاهج

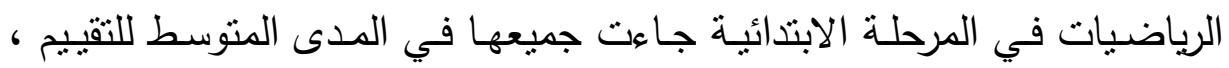
وجاء فى الترتيب الأول الفقرة رقم 0 من محور تصميم الدرس، وفئى الترتيب

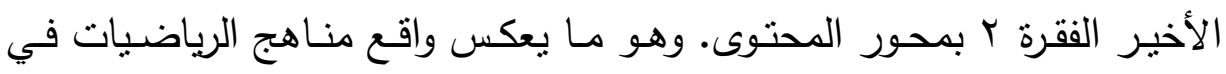
المرحلة الابتدائية حيث توقر خبرات كافية وفرص للمناقثة ولكنها غير مرتبطة

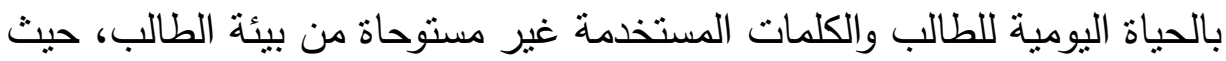
توجد كثير من الكلمات الغريبة منل (دعسوقة/الجداء) التي يجهل الطالب الكويتي معناها لعدم استخدامها في المجتمع الكويتي.

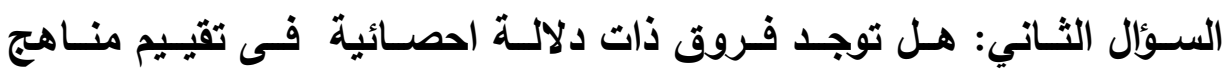

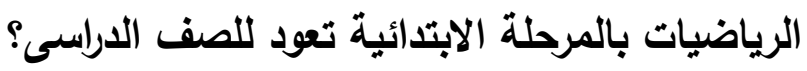

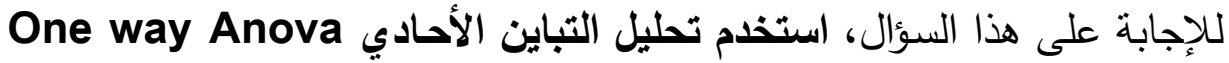

\begin{tabular}{|c|c|c|c|c|c|c|}
\hline الدلالة & |قيمة ف & متوسط الحرية & الدرجة & مجموع المربعات & & \\
\hline \multirow[t]{3}{*}{.871} & . 309 & .300 & 4 & 1.200 & بين المجموعات & \multirow{3}{*}{ المحتوى } \\
\hline & & .971 & 108 & 104.818 & داخل المجموعات & \\
\hline & & & 112 & 106.018 & ل المجموع & \\
\hline .934 & 207 & .141 & 4 & .564 & بين المجموعات & تصـيم \\
\hline
\end{tabular}

Doi: 10.12816/0038088 
مجلة الدراسات التربوية والانسانية ـ كلية التربية ـ جامعة دمنهور . المجلد السابع - العدد(r) - لسنة ه 10 ـ ب

\begin{tabular}{|c|c|c|c|c|c|c|}
\hline & & .680 & 108 & 73.470 & داخل المجموعات & \multirow[t]{2}{*}{ الدرس } \\
\hline & & & 112 & 74.034 & المجموع & \\
\hline \multirow{3}{*}{.904} & .258 & .316 & 4 & 1.265 & بين المجموعات & \multirow{3}{*}{ تنظيم المواد } \\
\hline & & 1.226 & 108 & 132.419 & داخل المجموعات & \\
\hline & & & 112 & 133.684 & المجموع & \\
\hline \multirow[t]{3}{*}{.922} & .228 & .227 & 4 & .908 & بين المجموعات & \multirow{3}{*}{ التقييم } \\
\hline & & .997 & 108 & 107.650 & داخل المجموعات & \\
\hline & & & 112 & 108.558 & المجموع & \\
\hline \multirow[t]{3}{*}{.653} & .615 & .820 & 4 & 3.280 & بين المجموعات & \multirow{3}{*}{ المساواة } \\
\hline & & 1.333 & 108 & 143.990 & داخل المجموعات & \\
\hline & & & 112 & 147.270 & المجموع & \\
\hline \multirow[t]{3}{*}{$\begin{array}{ll}.39 & \\
& 5 \\
\end{array}$} & $\begin{array}{l}1.0 \\
\quad 31 \\
\end{array}$ & .992 & 4 & 3.970 & بين المجموعات & \multirow{3}{*}{ المعايير تسلسـل } \\
\hline & & .962 & 108 & 103.933 & داخل المجموعات & \\
\hline & & & 112 & 107.903 & المجموع & \\
\hline \multirow[t]{3}{*}{$\begin{array}{ll}.96 & \\
& 4 \\
\end{array}$} & $\begin{array}{rr}.14 & \\
& 8 \\
\end{array}$ & .097 & 4 & .388 & بين المجموعات & \multirow{3}{*}{ 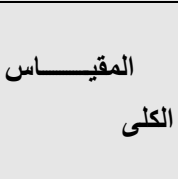 } \\
\hline & & .658 & 108 & 71.069 & داخل المجموعات & \\
\hline & & & 112 & 71.457 & المجموع & \\
\hline
\end{tabular}

جدول ^: تحليل التباين لحساب الفروق في تقييم منـاهج الرياضيات تبعا

\section{للصف في المرحلة الابتدائية}

تبين نتائج الجدول (^) إلى عدم وجود فروق ذات دلالـة احصـائية فى تقييم مناهج الرياضيات بين صفوف المرحلة الابتدائية من وجهة نظر المعلمات، حيث كانت قيم ف للمقياس الكلى و محاوره الفرعيـة غير دالة احصـائية عند مستوى

$$
\text { دلالة (0., (•) }
$$

وتشير تلك النتيجة الى عدم اختلاف مستوى منهج الرياضيات من حيث المحتوى وتصميم الارب، وتتظيم المواد، والتقييم، والمساواة، وتسلسل المعايير باختلاف الصفوف الدراسية بالمرحلة الابتدائية، وأن المعلمـات ترى أن المناهج بنفس المستوى بجميع الصفوف الاراسية بالمرحلة الابتدائية.

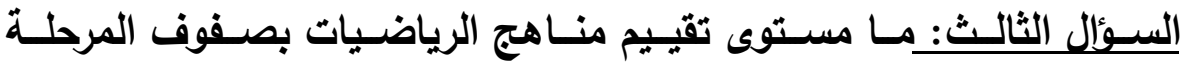
المتوسطة من وجهة نظر المعلمات؟ 
تقييم منهج الرياضيات في مراحل التعليم الأساسي في دولة الكويت د. دلال فرحان العنزي د. ابتسام العقل

للإجابـة على هذا السؤال تم حسـاب كل التكـرارات و النسـب المئوبـة و مـن المتوسط الحسابي والانحراف المعيارى ، لكل من فقرات الاستبيان و محاوره.

\begin{tabular}{|c|c|c|c|c|}
\hline |الترتيب & |لمستوى |لمي & الانحراف المعيارى & |لمتوسط الحسابى & \\
\hline 3 & متوسط & .972 & 2.93 & المحتوى \\
\hline 6 & متوسط & .877 & 2.63 & تصميم الدرس \\
\hline 2 & متوسط & 1.120 & 2.95 & تنظيم المواد \\
\hline 5 & متوسط & 1.102 & 2.84 & التقييم \\
\hline 4 & متوسط & 1.282 & 2.85 & المساواة \\
\hline 1 & متوسط & 1.098 & 2.95 & تسلسل المعايير \\
\hline & متوسط & .831 & 2.86 & المجموع \\
\hline
\end{tabular}

جدول 9: المتوسطات والانحرافات المعيارية لارجة التقييم لمنهج الرياضيات بالمرحلة المتوسطة

تشير نتائج الجدول (9) إلى إن تقييم المعلمات لمناهج الرياضيات بالمرحلة المتوسطة كان متوسط، المستوى حيث بلغن المتوسط الحسابي جم,ب وهو فى المدى المتوسط للتقييم. وجاء تقييم جميع محاور الاستبيان فى المدى المتوسط

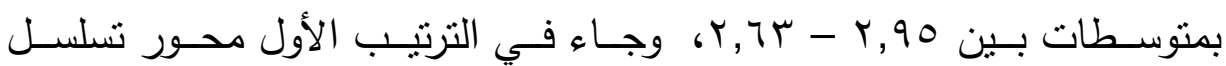
المعايير ، وفى الترنيب الأخير محور تصميم الدرس. ويعرض الجدول التالي تقييم عينة الدراسة لبنود الاستبيان : تصنيان

\begin{tabular}{|c|c|c|c|c|c|c|}
\hline الترتيب & 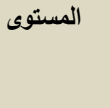 & 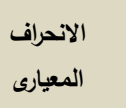 & المتوسط الحسابى & 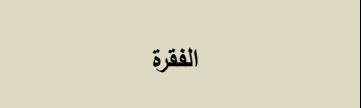 & p & 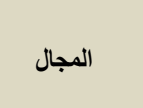 \\
\hline 1 & متوسط & 1.321 & 3.12 & 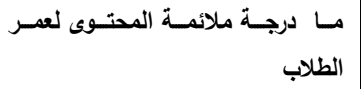 & 1 & \multirow{2}{*}{ المحتوى } \\
\hline ir & متوسط & 1.017 & 2.74 & ارتباطه بالحياة اليومية الهمية المحتوى مسن حيث & r & \\
\hline 10 & 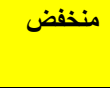 & 1.186 & 2.57 & بصورة متوازنة ومنوعة نماذج الاستقصاء العلمى & $r$ & \multirow{3}{*}{ تصميم الدرس } \\
\hline ir & متوسط & 1.093 & 2.69 & فعالة تدل على فهمهم الطلاب الأنثطة بطريقـة & $\varepsilon$ & \\
\hline $1 \varepsilon$ & متوسط & 1.245 & 2.64 & هـل هنــاك خبـرات كافيـة و فـرص & $\bullet$ & \\
\hline
\end{tabular}




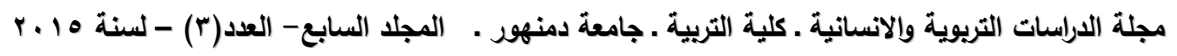

\begin{tabular}{|c|c|c|c|c|c|c|}
\hline الترتيب & المستوى & المعيارى & المتوسط الحسابى & الفقرة & p & المجال \\
\hline & & & & اللفهن اقثـة تصكن الطـلاب مـن تطوير & & \\
\hline - & متوسط & 1.304 & 2.93 & 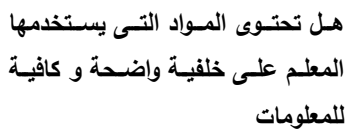 & 9 & \multirow{4}{*}{ تنظيم المواد } \\
\hline$\varepsilon$ & متوسط & 1.086 & 2.96 & 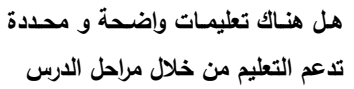 & v & \\
\hline 4 & متوسط & 1.440 & 2.92 & سهلة يستـذابعة المعلم صنيل الطلاب و تراكيب & $\wedge$ & \\
\hline$r$ & متوسط & 1.406 & 2.98 & هله تم تحيدا الوسائل اللازمـة لتنفيذ & 9 & \\
\hline 11 & متوسط & 1.268 & 2.78 & اللازلاب و المعلمون مزوديون بالأدوات & 1. & \multirow[t]{2}{*}{ التقييم } \\
\hline v & متوسط & 1.145 & 2.91 & هل ير الرسمى التقيِيم البعدين الرسمى و & 11 & \\
\hline 9 & متوسط & 1.711 & 2.88 & 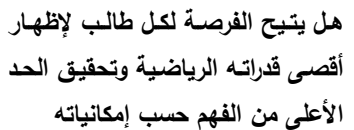 & ir & \multirow[t]{2}{*}{ المساواة } \\
\hline 1. & متوسط & 1.160 & 2.83 & 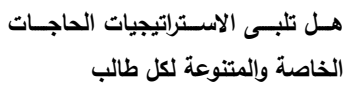 & $1 \pi$ & \\
\hline$\wedge$ & متوسط & 1.267 & 2.91 & 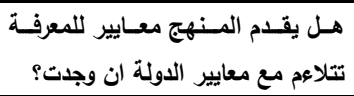 & $1 \varepsilon$ & \multirow{2}{*}{ المعايير تسلســـل } \\
\hline r & متوسط & 1.123 & 2.99 & 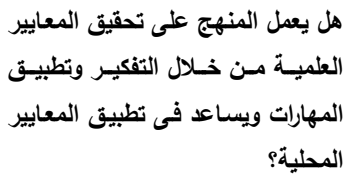 & 10 & \\
\hline
\end{tabular}

جدول · 1: نسب الاستجابة لبنود استبيان تقييم منهج الرياضيات بالمرحلة

المتوبطة

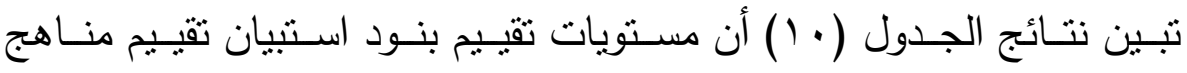
الرياضيات بالمرحلـة المتوسطة تراوحت بين المتوسط الـى المنخفض ، وكان

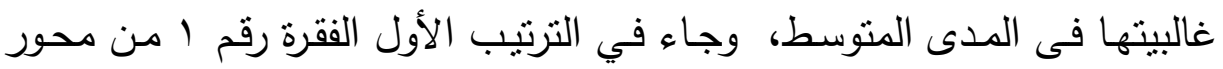

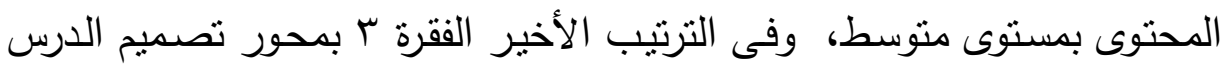


تقييم منهج الرياضيات في مراحل التعليم الأساسي في دولة الكويت د. دلال فرحان العنزي د. ابتسام العقل

بمستوى منخفض. بشكل عام محتوى مناهج الرباضيات في المرحلة المتوسطة مناسـب لعمـر التـلاميذ ولكنه يفتقر لأسـاليب الاستقصـاء العلمي بصـورة منوازنة ومنتوعة.

السؤال الرابع: هل توجد فروق ذات دلالة احصائية فى تقييم مناهج الرياضبات بالمرحلة المتوسطة تعود للصف الاراسي؟

One way للإجابة على هذا السؤال تم استخدام تحليل التباين الأحادي

anova

\begin{tabular}{|c|c|c|c|c|c|c|}
\hline الدلالة & قيمة ف & متوسط الحرية & درجة الحرية & مجموع المربعات & & \\
\hline \multirow[t]{3}{*}{.871} & .309 & .300 & 3 & .299 & بين المجموعات & \multirow{3}{*}{ المحتوى } \\
\hline & & .971 & 85 & 82.796 & داخل المجموعات & \\
\hline & & & 88 & 83.096 & المجموع & \\
\hline \multirow[t]{3}{*}{.934} & .207 & .141 & 3 & .609 & بين المجموعات & \multirow{3}{*}{ تصميم الدرس } \\
\hline & & .680 & 85 & 67.005 & داخل المجموعات & \\
\hline & & & 88 & 67.613 & المجموع & \\
\hline \multirow[t]{3}{*}{.904} & .258 & .316 & 3 & .797 & بين المجموعات & \multirow{3}{*}{ تنظيم المواد } \\
\hline & & 1.226 & 85 & 109.637 & داخل المجموعات & \\
\hline & & & 88 & 110.434 & المجموع & \\
\hline \multirow[t]{3}{*}{.922} & .228 & .227 & 3 & .670 & بين المجموعات & \multirow{3}{*}{ التقييم } \\
\hline & & .997 & 85 & 106.127 & داخل المجموعات & \\
\hline & & & 88 & 106.798 & المجموع & \\
\hline \multirow[t]{3}{*}{.653} & .615 & .820 & 3 & 1.479 & بين المجموعات & \multirow{3}{*}{ المساواة } \\
\hline & & 1.333 & 85 & 143.122 & داخل المجموعات & \\
\hline & & & 88 & 144.601 & المجموع & \\
\hline \multirow[t]{3}{*}{.395} & 1.031 & .992 & 3 & 2.788 & بين المجموعات & \multirow{3}{*}{ لمعايير تسلسـل } \\
\hline & & .962 & 85 & 103.234 & داخل المجموعات & \\
\hline & & & 88 & 106.022 & المجموع & \\
\hline \multirow[t]{3}{*}{.964} & .148 & .097 & 3 & .035 & بين المجموعات & \multirow{3}{*}{ المقيــــــــاس } \\
\hline & & .658 & 85 & 60.732 & داخل المجموعات & \\
\hline & & & 88 & 60.766 & المجموع & \\
\hline
\end{tabular}

Doi: $10.12816 / 0038088$ 
جدول 11 : تحليل التباين لحساب الفروق في تقييم منـاهج الرياضيات تبعا للصف بالمرحلة المتوسطة تبين نتائج الجدول (1') إلى عدم وجود فروق ذات دلالة احصائية فى تقييم منـاهج الرياضيات بين صفوف المرحلة المنوسطة من وجهة نظر المعلمـات،

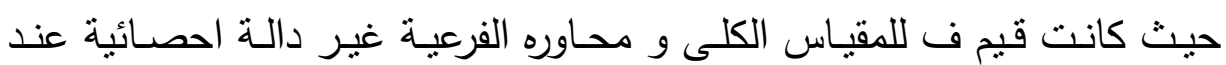

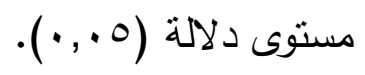

وتثير تلك النتيجة الى عدم اختلاف مستوى منهج الرياضيات من حيث

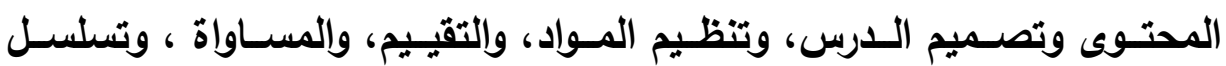

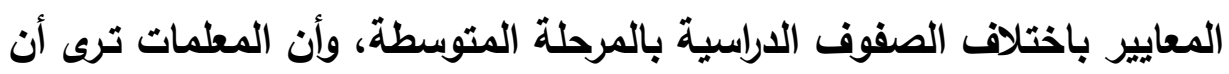
المناهج بنفس المستوى بجميع الصفوف الدراسية بالمرحلة الابتدائية. السـؤال الخـامس : مـا مستوى تقيـيم منـاهج الرياضسيات عامـة بـالمرحلتين الابتدائية و المتوسطة من وجهة نظر المعلمات؟ للإجابـة على هـذا السؤال تـم حسـاب كل التكـرارات و النسـب المئويـة ومـن المتوسط الحسابي والانحراف المعياري، لكل من فقرات الاستبيان ومحاوره.

\begin{tabular}{|c|c|c|c|c|}
\hline ب التـرت & المستوى & المعيارى & الحسابى & \\
\hline 3 & متوسط & .973 & 2.84 & المحتوى \\
\hline 6 & متوسط & .847 & 2.76 & تصميم الدرس \\
\hline 1 & متوسط & 1.104 & 2.88 & تنظيم المواد \\
\hline 4 & متوسط & 1.036 & 2.79 & التقييم \\
\hline 5 & متوسط & 1.207 & 2.77 & المساواة \\
\hline 2 & متوسط & 1.035 & 2.86 & تسلسل المعايير \\
\hline & متوسط & .812 & 2.81 & المجموع \\
\hline
\end{tabular}

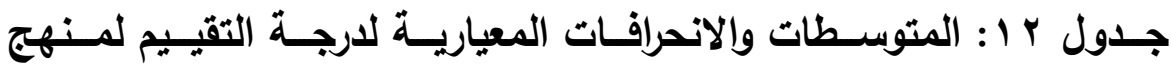
الرياضيات بالمرحلتين الابتدائية والمتوسطة 


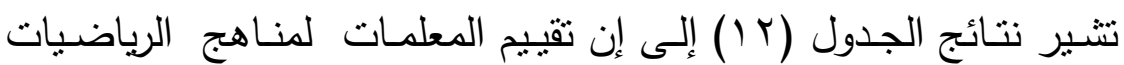
بالمرحلنين الابتدائية و المتوسطة كان متوسط، المستوى حيث بلغ المتوسط

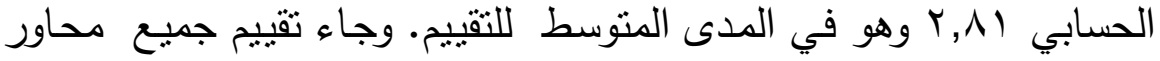

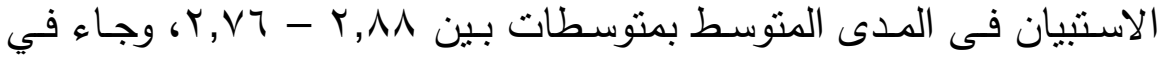

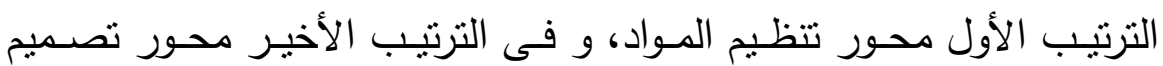
الدرس. ويعرض الجدول التالي تقييم عينة الدراسة لبنود الاستبيان :

\begin{tabular}{|c|c|c|c|c|c|c|}
\hline | الترتيب & المستوى - الم & 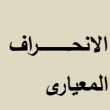 & الحسابى المتوســــــ & الفقرة & b & المجال \\
\hline 1 & متوسط & 1.268 & 3.01 & ما درجة ملائمة المحتوى لعمر الطلاب & 1 & \multirow{2}{*}{ 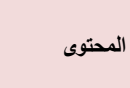 } \\
\hline 10 & متوسط & 1.004 & 2.67 & ما درجة أهمية المحتوى من حيث ارتباطه بالحياة اليومية & r & \\
\hline $1 \varepsilon$ & متوسط & 1.073 & 2.69 & هل يستخدم نماذج الاستقصاء العلمى بصورة متوازنة ومنوعة & r & \multirow{3}{*}{ تصميم الارس } \\
\hline 11 & متوسط & 1.043 & 2.76 & هلمتوى يمارس الطلاب الأنثطة بطريقة فعالة تدل على فهمهح & $\varepsilon$ & \\
\hline$\wedge$ & متوسط & 1.179 & 2.82 & تطوير الفهر خبرات كافية و فرص للمناقثـة تمكن الطلاب من & - & \\
\hline r & متوسط & 1.292 & 2.94 & كافية لمعلوى المواد التى يستخدمها المعلم على خلفية واضحة و & 1 & \multirow{4}{*}{ تنظيم المواد } \\
\hline$\varepsilon$ & متوسط & 1.183 & 2.87 & مراحل هلاكت تعليمـات واضحة و محددة تـعم التعليم من خلال & $\mathrm{v}$ & \\
\hline$\checkmark$ & متوسط & 1.430 & 2.84 & هل يستخدم المعلم صيغا و تراكيب سهلة المتابعة من قبل & $\wedge$ & \\
\hline 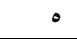 & 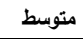 & 1.419 & 2.86 & هل تم تحديد الوسائل اللازمة لتنفيذ المنهج مسبقا & 9 & \\
\hline ir & متوسط & 1.211 & 2.74 & 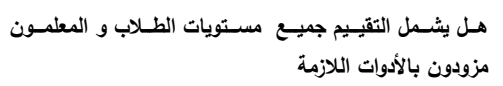 & 1. & \multirow[t]{2}{*}{ التقييم } \\
\hline $\mathrm{v}$ & متوسط & 1.093 & 2.83 & هل يراعى التقييم البعدين الرسمى و غير الرسمى & 11 & \\
\hline 1. & متوسط & 1.644 & 2.77 & 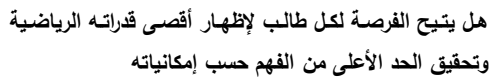 & ir & \multirow{2}{*}{ 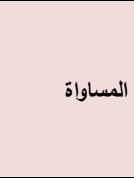 } \\
\hline ir & متوسط & 1.134 & 2.76 & طالب هل تلبى الاسترترتيجيات الحاجـات الخاصـة و المتنوعـة لكل & ir & \\
\hline a & متوسط & 1.165 & 2.81 & وجدت يقدم المنهج معايير للمعرفة تتلاءم مع معايير الدولة ان & $1 \varepsilon$ & \multirow[b]{2}{*}{ تسلسل المعايير } \\
\hline r & متوسط & 1.095 & 2.91 & 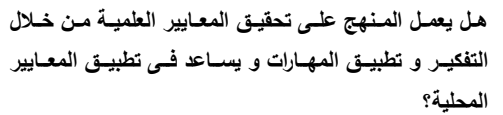 & 10 & \\
\hline
\end{tabular}


جدول با 1 : نسب الاستجابة لبنود تقييم منهج الرياضيات بالمرحلة الابتدائية

\section{والمتوسطة}

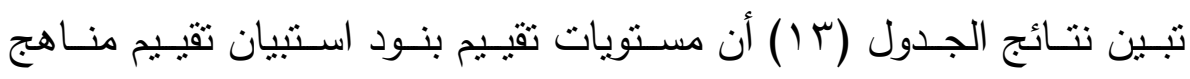
الرياضيات بالمرحلة الابتدائية و المنوسطة جاءت جميعها فى المدي المتوسط،

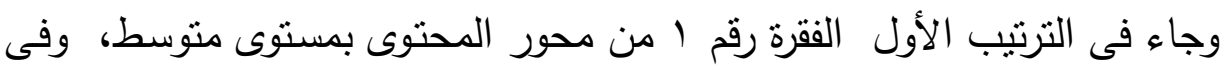
الترتيب الأخير الفقرة ب بمحور المحتوى بمستوى متوسط.

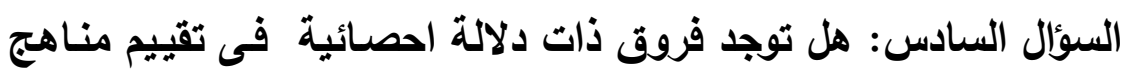

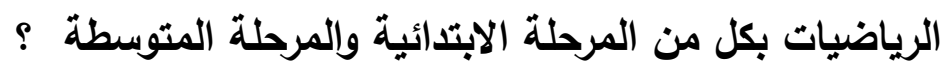
للإجابة على هذا السؤال قامت الباحثون باستخدام اختبار ت للفروق بين المجموعات Independent Sample t-test للتعرف على الفروق تقييم

المناهج تبعا للمرحلة الدراسية

\begin{tabular}{|c|c|c|c|c|c|c|}
\hline \multirow{2}{*}{ الدلالة } & \multirow{2}{*}{ ت ت } & \multicolumn{2}{|c|}{ 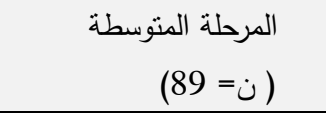 } & \multicolumn{2}{|c|}{ 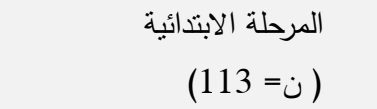 } & \\
\hline & & الالنحـــراف & الحسابى المتوســـــ & 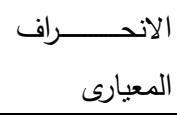 & 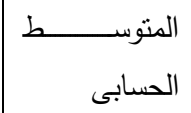 & \\
\hline .239 & 1.180 & .972 & 2.93 & .973 & 2.77 & المحتوى \\
\hline .064 & 1.863 & .877 & 2.63 & .813 & 2.86 & تصميم الدرس \\
\hline .423 & -.804 & 1.120 & 2.95 & 1.093 & 2.82 & تتظيم المواد \\
\hline .500 & -.675 & 1.102 & 2.84 & .985 & 2.74 & التقييم \\
\hline .367 & -.904 & 1.282 & 2.85 & 1.147 & 2.70 & لمساواة \\
\hline .271 & 1.104 & 1.098 & 2.95 & .982 & 2.79 & تسلسل المعايير \\
\hline .510 & -.659 & .831 & 2.86 & .799 & 2.78 & المقياس الكلى \\
\hline
\end{tabular}

جدول \& 1 : اختبار ت لحسـاب الفروق في تقيّيم منـاهج الرياضيات تبعا

\section{للمرحلة الاراسية}

نبين نتائج الجدول (ع () إلى عدم وجود فروق ذات دلالة احصائية فى تقييم

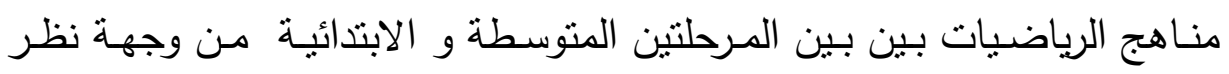

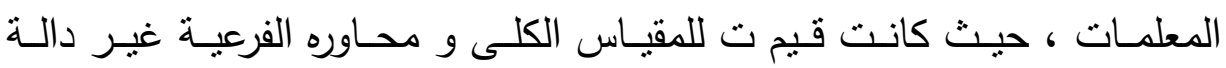


تقييم منهج الرياضيات في مراحل التعليم الأساسي في دولة الكويت د. دلال فرحان العنزي د. ابتسام العقل

احصـائية عند مستوى دلالة (0. . •). وتثـير تلك النتيجـة السى عدم اختلاف

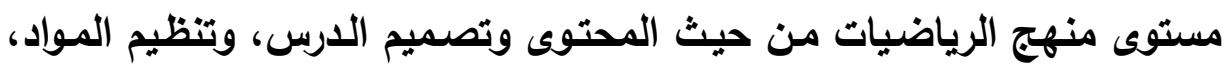

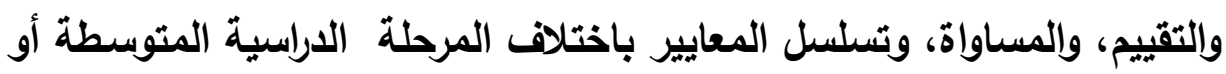
الابتدائية، وأن المعلمات ترى أن المناهج بنفس المستوى بالمرحلتين الابتذائية

والمتوسطة.

الخاتمة:

هدفت هذه الدراسـة لتقييم منهج الرياضيات في مراحل التعليم الأساسي في دهي دولة الكويت من وجهة نظر معلمي مادة الرياضيات،

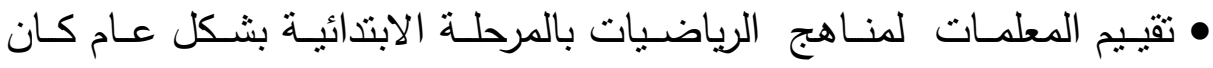

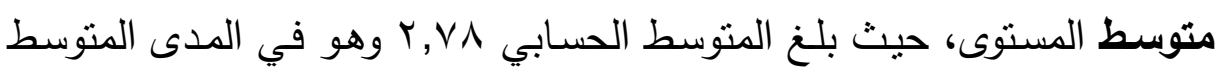
للاتقيم. وجاء في الترتيب الأول محور تصميم الدرس، و في الترتيب الأخير محور المساواة. مستويات تقييم بنود استبيان تقييم مناهج الرياضيات في المرحلة

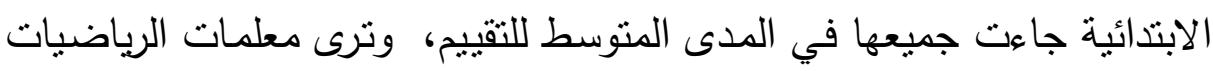

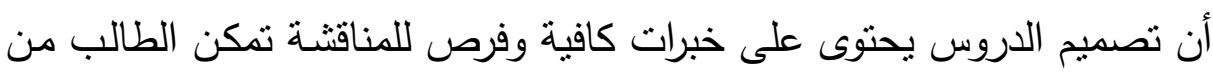

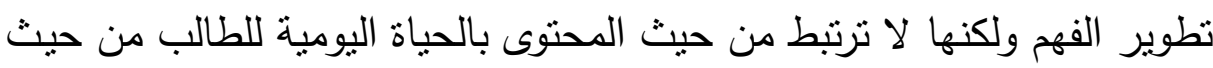
المصطلحات والأمثلة المستخدمة. ترى معلمات الرياضيات في المرحلة الابتدائية

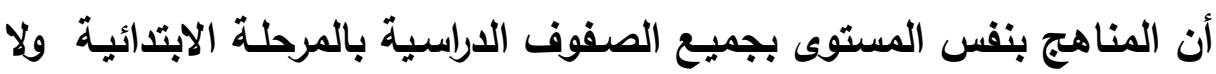
يوجد اختلاف مستوى منهج الرياضيات من حيث المحتوى و تصميم الدرس،

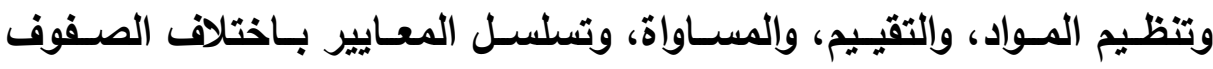
الدراسية بالمرحلة الابتدائية.

• تقييم المعلمات ل لمناهج الرياضيات بالمرحلة المتوسطة أيضا كان متوسط،

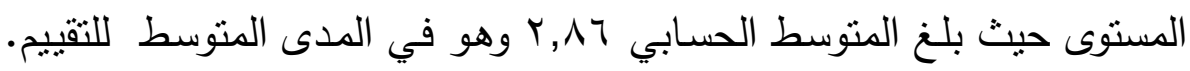
وجاء في الترتيب الأول محور تسلسل المعايير، وفي الترتيب الأخير محور تصميم الدرس. مستويات نقييم بنود استبيان تقييم مناهج الرياضيات بالمرحلة 
المتوسطة تراوحت بين المتوسط إلى المنخفض، وكان غالبيتها في المدى المتوسط، بشكل عام ترى معلمات الرياضيات أن محتوى مناهج الرياضيات

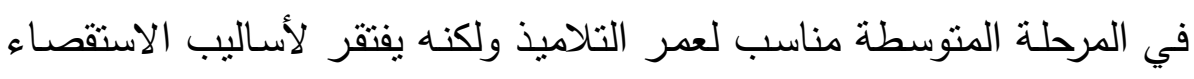

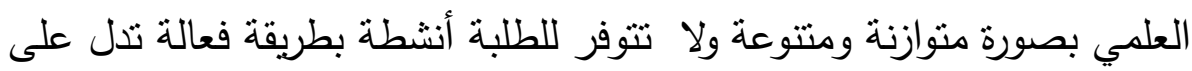

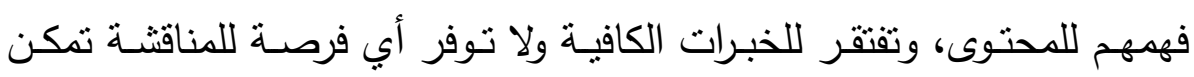

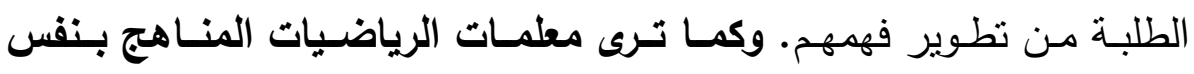

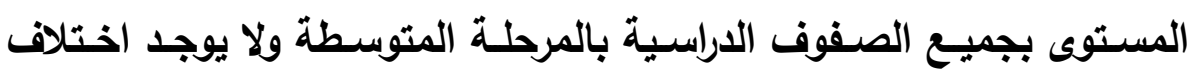
مستوى منهج الرياضيات من حيث المحتوى وتصميم الدرس، وتنظيم المواد، والتقييم ، والمساواة ، وتسلسل المعايير باختلاف الصفوف الدراسية بالمرحلة المتوسطة.

\section{في ضوء هذه النتائج الدراسة نوصي بما يلي:}

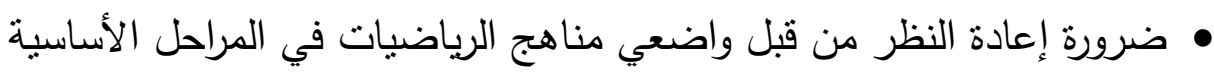

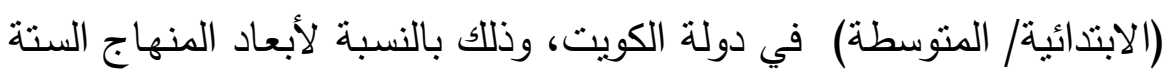

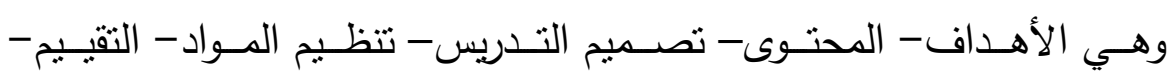
المساواة- تسلسل المعايير مع ضرورة الأخذ بوجهة نظر المعلمين عند القيام بتعديل المناهج من قبل القائمين عليها ذلك أن للمعلم رؤيته الخاصة بالمنهاج كونه هو المنفذ لهذه المناهج. • ضرورة تأهيل معلمين الرياضيات بشكل يناسب المنهاج الحديث عن طريق

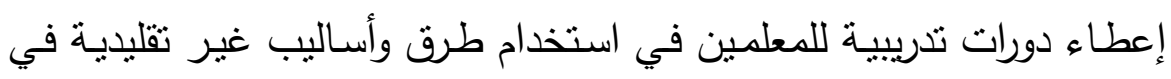

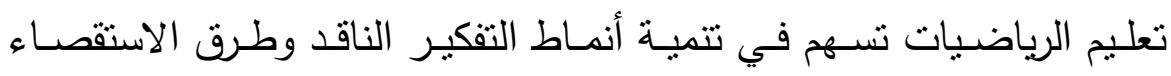
والبحث العلمي. 
تقييم منهج الرياضيات في مراحل التعليم الأساسي في دولة الكويت د. دلال فرحان العنزي د. ابتسام العقل 


\section{قائمة المراجِي}

\section{أولاً: المراجيع العربية:}

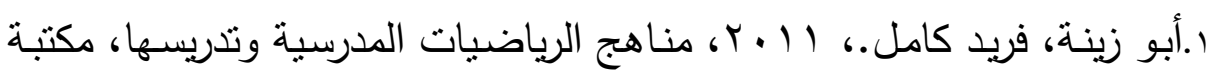

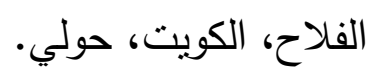

r.الخطيب، محمود محمد.، و الزعبي، على محمد.، (9 . . r)، دراسـة تقويمية

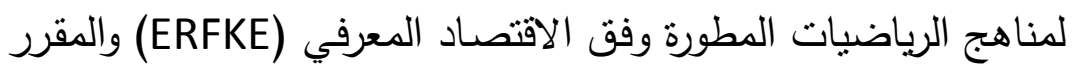

تدريسها لطلبة صفوف المرحلة الأساسية (الرابع، الثامن، العاشر ) في الثياسي

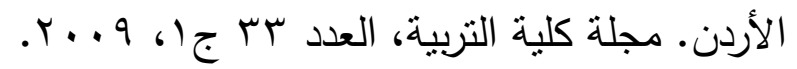

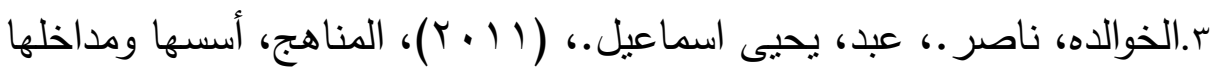

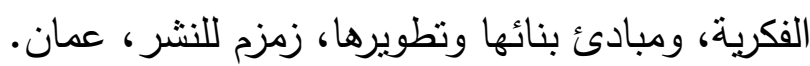

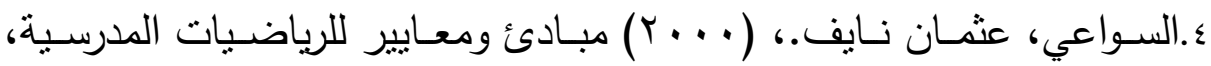

National Council of teacher of mathematics ترجمة ل (2000). Principle and standards for School mathematics.

Reston.http://www.arabeducators.com/arabeducators/ portals/0/cv/1422011222922897.pdf

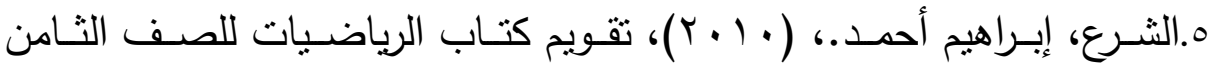

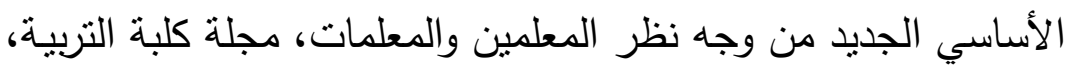

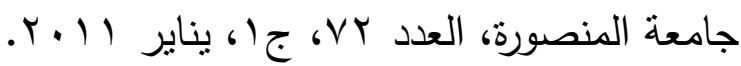

4.العقلا ، عبدالعزيز (IV I ا هـ) ـ مواطن الضعف والقوة في منهج الرياضيات

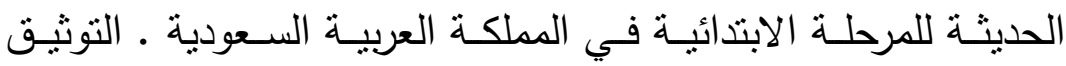

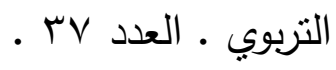

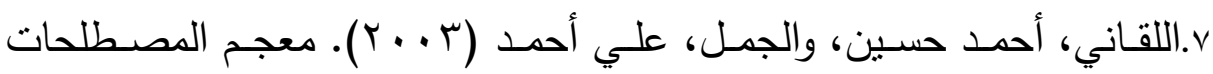

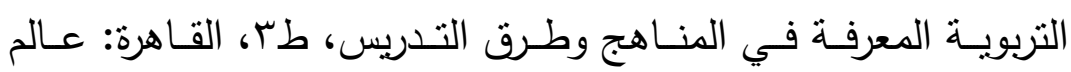




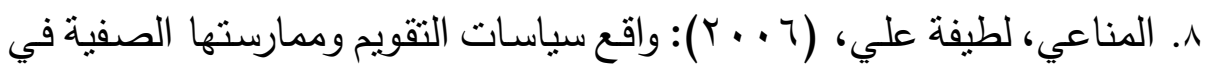
المدارس الابتدائية في البحرين " رسالة دكتوراه، مركز البحوث

$$
\text { والدراسات التربوية والمناهج، الكوبت. }
$$

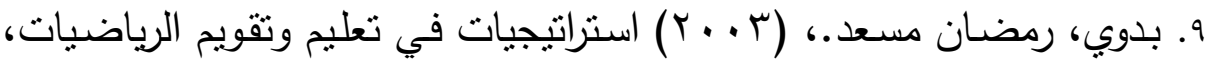

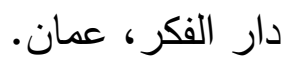

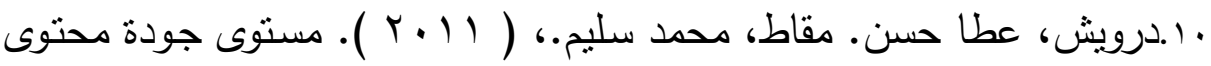

منهـاج الرياضـيات الفلسـطيني للصـفوف الثالـث والرابـع والخـامس

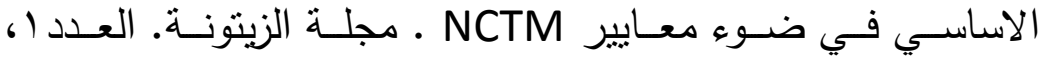

$$
.11
$$

111 السـنة ا ا • ب في الدول العربيـة، المنظمـة العربيـة للتربيـة

والتقافة والعلوم.

rا.عبدالرحمن ، يس ( 919 (م ) : التدريس وإعداد المعلم ، طب ، الرياض ،

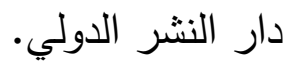

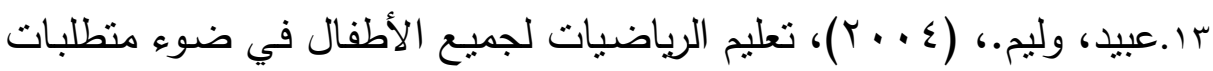
المعايير وثقافة التفكير ، دار المسيرة، عمان.

ـ ا.يـونس، سـمير .، الرثـيدي، سـعد.، العنيزي، يوسـف.، سـلامة، عبدالرحيم.،

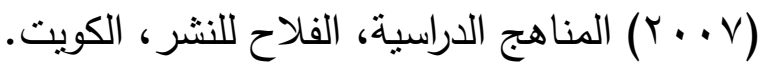

\section{ثانيًا : المراحِ الاحنية}

15.Mullis, Ina V.S., . Martin, M.O., Foy, P., \& Arora, A. (2012). TIMSS 2011 International Results in Mathematics, (IEA), Publisher: TIMSS \& PIRLS International Study Center, Lynch School of Education, Boston College, Chestnut Hill, MA, USA

http://timss.bc.edu/TIMSS2011/downloads/T11_IR_Mathematics_FullB ook.pdf

16.National Council of teacher of mathematics (2000). Principle and standards for School mathematics. Reston, VA: Author. 